\title{
Notes
}

\section{Federal Compensation for Victims of the "Homeownership for the Poor" Program}

It is probably inevitable that, in any government program, not all of the participants will be benefited to as great a degree as the program's proponents would have hoped. But the federal "homeownership for the poor" program ${ }^{1}$ is unusual; thousands ${ }^{2}$ of participants actually were left in a far worse condition ${ }^{3}$ than before they took part in the program.

To date, all suits for damages that participants have brought against the federal government have been unsuccessful, ${ }^{4}$ and remedial legislation $^{5}$ enacted by Congress has been woefully inadequate. ${ }^{6}$ This

1. National Housing Act $\$ \S 235,221$ (d)(2), 12 U.S.C. $\$ \S 1715 z, 1715 l(d)(2)(1970)$.

2. See Stegman, Low-Income Ownership: Exploitation and Opportunity, $50 \mathrm{~J}$. URBAN L. 371, 375-77 (1973); Comment, Property Abandonment in Detroit, 20 WAYNE L. REv. 845, 858-64 (1974) [hereinafter cited as Property Abandonment]; Note, Exploiting the Home-Buying Poor: A Case Study of Abuse of the National Housing Act, 17 Sr. Lovis U.L.J. 525 \& n.3 (1973) [hereinafter cited as Exploiting the Home-Buying Poor]; Note, Abuses in the Low Income Homeownership Programs-The Need for a Consumer Protection Response by the FHA, 45 TEMP. L.Q. $461,471 \& \mathrm{n} .52$ (1972) [hereinafter cited as Abuses].

3. See sources cited in note 2 supra. See also Special Pennsylvania State Task Force, Final Report on Real Estate Sales Practices in Eastern Pennsyluania (1972) [herein. after cited as PA. TASK Force Final Report] (on file with the Yale Law Journal). This is not to say that no one was helped or that the homeownership for the poor idea should be dropped permanently as hopeless. See Singer, Landon \& Graham, Section 235 Housing: One Empirical Study with Recommendations for the Future, 7 IND. L. REv. 773, 813 (1974) (concludes that " $[t]$ he section 235 program should not be abandoned since its benefits ap. pear to be great and its problems controllable") [hereinafter cited as Empirical Study].

4. Plaintiff' damage claims have been dismissed in: Davis v. Romney, 355 F. Supp. 29 (E.D. Pa. 1973), aff'd as to dismissal of damage claim and vacated and remanded as to injunctive relief, 490 F.2d 1360 (3d Cir. 1974); Perry v. Romney, Civil No. 9347 (W.D. Wash. Apr. 5, 1971), appeal dismissed as moot, 472 F.2d 565 (9th Cir. 1973); Jackson v. Romney, 355 F. Supp. 737 (D.D.C. 1973), aff'd sub nom. Jackson v. Lynn, Civil No. 73-1510 (D.C. Cir. Oct. 17, 1974); Cason v. United States, Civil No. 19025-2 (W.D. Mo. Apr. 5, 1973) (partial summary judgment denying damage claim), (W.D. Mo. July 8, 1974) (dismissing other claims), appeal docketed, No. 74-1672, 8th Cir., Aug. 23, 1974; Massey v. Lynn, Civil No. 39822 (E.D. Mich. June 27, 1974), appeal docketed, No. 74-2122, 6th Cir. Oct. 14, 1974; Nash v. Romney, Givil No. 72-1313-RJK (C.D. Cal. Oct. 15, 1973); Pollard v. Romney, Civil No. 73.91 (W.D. Pa. Feb. 6, 1974). There are no reported cases, and apparently no unreported ones either, where such plaintiffs have won damages against the government.

It is true, however, that plaintiffs in two cases-Davis v. Romney, supra, and Bailey v. Romney, 359 F. Supp. 596 (D.D.C. 1973), government's appeal dismissed per stipulation, No. 73-2036 (D.C. Cir. Jan. 11, 1974), plaintiffs' appeal docketed, No. 73-2007, D.C. Cir., July 25, 1973-have won injunctions against the government. As to the inadequacies of injunctions in these situations, see p. 302 infra.

5. National Housing Act $\S 518,12$ U.S.C. $\$ 1735 \mathrm{~b}(1970)$, as amended, Housing \& Community Development Act of 1974, Pub. L. No. 93-383, $\S 306,88$ Stat. 678.

6. See pp. 303-06 infra. 
Note concludes that many of these low-income homeownership victims should be held entitled to damages against the United States even under the present limited waiver of sovereign immunity represented by the Federal Tort Claims Act, ${ }^{7}$ but also that Congress should enact legislation to provide expeditious and full recompense to all such people and should consider broader legislation to ensure that future hapless victims of government programs will not go remediless.

\section{Background}

In $1968,{ }^{8}$ Congress launched a major effort ${ }^{9}$ to promote homeownership for low-income families by enacting $\S 235^{10}$ of the National Housing Act. ${ }^{11}$ The program authorized the Federal Housing Administration (FHA) of the Department of Housing and Urban Development (HUD) to insure mortgages on homes sold to low-income buyers ${ }^{12}$ through a special risk insurance fund. ${ }^{13}$ The mortgage could be for as much as 97 percent of the value of the property, ${ }^{14}$ and the buyer's down payment could be as little as $\$ 200$, a sum which could be used to pay closing costs. ${ }^{15}$ In addition, $\S 235$ authorized the Secretary of HUD to make payments directly to the mortgagee on behalf of the low-income buyer-mortgagor, ${ }^{10}$ so that the buyermortgagor's effective mortgage interest rate could be reduced to as little as one percent, ${ }^{17}$ depending on the size and income of the buyer-mortgagor's family. ${ }^{18}$ Statutory changes in 1968 also enabled more low-income people to purchase homes under $\S \S 221(\mathrm{~d})(2)^{19}$ and

7. 28 U.S.C. $\S \S 1346(\mathrm{~b}), 2674-80$ (1970).

8. Act of Aug. 1, 1968, Pub. L. No. 90-448, $\$ 101$ (a), 82 Stat. 476.

9. Le Clercq, Entitlement Under Section 235 of the National Housing Act, 25 S.C.L.

REv. 1, 3 (1973); Schafer \& Field, Section 235 of the National Housing Act; Homeownership for Low Income Families?, 46 J. URBAN L. 667, 667-70 (1969).

10. 12 U.S.C. $\$ 1715 z(1970)$.

11. Id. $\$ \$ 1701$ et seq.

12. As defined by id. $\S 1715 \mathrm{z}(\mathrm{h})(2)$. See Le Clercq, supra note 9, at 18, 26-28. See generally Schafer \& Field, supra note 9 .

13. 12 U.S.C. $\$ 1715 \mathrm{z}-3$ (1970).

14. Id. $\$ 1709(\mathrm{~b})(2)$.

15. Id. $\$ 1715 z(\mathrm{i})(3)(\mathrm{C})$. The minimal $\$ 200$ down payment in lieu of the full three percent down payment will no longer be allowed. Pub. L. No. 93-383, § 211(a)(6), 88 Stat. 671.

16. 12 U.S.C. $\S 1715 z$ (a) (1970).

17. Id. $\$ 1715 \mathrm{z}(\mathrm{c})$.

18. See generally C. Edson \& B. Lane. A Practical Guide to Low- and Moderate-INCOME Housing 5:1-5:14 (1972); Schafer \& Field, supra note 9.

19. 12 U.S.C. $\$ 1715 l(\mathrm{~d})(2)$ (1970). See Exploiting the Home-Buying Poor, supra note 2, at 527-28; Hearings on Defaults on FHA-Insured Mortgages (Detroit) Before the Subcomm. on Legal i Monetary Affairs of the House Comm. on Government Operations, $92 \mathrm{~d}$ Cong., lst Sess. 2-4 (1971); Property Abandonment, supra note 2, at 859-60. 
$203^{20}$ of the National Housing Act-sections originally enacted prior to $1968^{21}$-even though they still do not provide for financial assistance from FHA. ${ }^{22}$

Some hailed the 1968 legislation as "perhaps the most significant piece of housing legislation ever enacted in this country," ${ }_{23}$ designed to enable thousands, even millions, of the poor ${ }^{24}$ to realize the American dream of owning a single-family, detached home. ${ }^{25}$ Homeownership, many felt, would "give lower income groups a 'stake in society' and would increase both their sense of responsibility and of community"26-significant benefits to all of American society in the wake of the then-recent urban riots. ${ }^{27}$

But the low-income homeownership program encountered severe problems almost immediately, because the low-income participants lacked homebuying sophistication, ${ }^{28}$ because FHA was not prepared to administer such a large scale and radically new program, ${ }^{20}$ and because the mortgage insurance was structured in a way that actually made it in the interest of lenders to loan money on uninhabitable

20. 12 U.S.C. $\$ 1709$ (1970). See Exploiting the Home-Buying Poor, supra note 2, at 527-28; Hearings on Defaults on FHA-Insured Mortgages (Detroit) Before the Subcomm. on Legal \& Monetary Affairs of the House Comm. on Government Operations, 92d Cong., 1st Sess. 2-4 (1971); Property Abandonment, supra note 2, at 859-60.

21. Section 221(d)(2) was originally enacted as Act of Aug. 2, 1954, ch. 649, $\$ 123,68$ Stat. 599. Section 203 was originally enacted as Act of June 27, 1934, ch. 847, $\$ 203,48$ Stat. 1248.

22. See sources cited in notes 19-20 supra.

23. Freilich \& Seidel, Recent Trends in Housing Law: Prologue to the 70's, 2 URB.AN LAw. 1, 4 (1970) (referring to $\$ \$ 235,236$ ).

24. Id. Freilich and Seidel felt, however, that the programs would not reach the "hard core" poor, id., and they were joined in this feeling by Berger, Homeownership for Lower Income Families: The 1968 Housing Act's "Cruel Hoax", 2 ConN. L. REv. 30 (1969).

25. See Le Clercq, supra note 9 , at 5 .

26. See Property Abandonment, supra note 2, at 860 .

27. Id. at 859.60.

28. In one study, "virtually none of the section 235 purchasers ... had lived in his own home prior to his section 235 purchase." Empirical Study, supra note 3, at 787. See

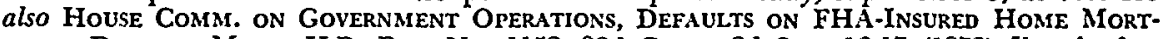
Gages-Detroit, Mich., H.R. Rep. No. 1152, 92d Cong., 2d Sess. 16-17 (1972) [hereinafter cited as Holifield Report]; PA. TASK FORCE FINAL REPORT, supra note 3, at 6; Special Project, The 235 Housing Program in Action: An Empirical Examination of its Adminis. tration and Effect on the Homeowner-Participant in the Columbia, South Carolina Area, 25 S.C.L. REv. 93, 130-31 (1973) [hereinafter cited as Special Project]; Exploiting the Home-Buying Poor, supra note 2, at 525.

29. This was due both to shortage of staff, Holifield Report, supra note 28, at 22-25, and to what HUD Secretary George Romney termed the difficulty of attempting

to change the organizational thinking of an organization [FHA] that has been reviewing things purely from a credit standpoint to a consumer oriented organization which is required to administer this program successfully....

Hearings on HUD Investigation of Low-and Moderate-Income Housing Programs Before the House Comm. on Banking and Currency, 92d Cong., Ist Sess. 18 (1971) (titled as "Interim Report on HUD Investigation of Low- and Moderate-Income Housing Programs") [hereinafter cited as HUD Investigation Hearings]. 
homes. ${ }^{30}$ These features attracted a host of unscrupulous realtorsellers $^{31}$ and finance company mortgagees. ${ }^{32}$ Often in combination with corrupt HUD employees and contractors, ${ }^{33}$ they foisted on thousands ${ }^{34}$ of unwary participants "homes in dire need of complete rehabilitation ...., [homes] which should have been razed ...., [homes having] no resale value ....."35

The House Committee on Government Operations described as typical $^{30}$ the case of Maurdell Harris, who bought a home in Detroit under $\$ 221(\mathrm{~d})(2)$ and discovered, shortly after moving into the house with her husband and nine children, that the furnace did not work, that the electricity had to be turned off "for the sake of safety" due to a short circuit, and that the gas service had to be discontinued because of a gas leak. ${ }^{37}$ Since Mrs. Harris paid $\$ 12,650$ to a real estate speculator who had bought the house six months earlier for $\$ 6,000,{ }^{38}$ the Committee concluded that "what the real estate speculator had turned over to Mrs. Harris, at a 100 percent profit to himself, was little more than a wooden shell unfit for human habitation." 39

Mrs. Harris and her family apparently did not suffer any physi-

30. Hood \& Kushner, Real Estate Finance: The Discount Point System and Its Effect on Federally Insured Home Loans, 40 U. Mo. K.C.L. REv. 1, 18 (1971). See also Exploiting the Home-Buying Poor, supra note 2, at 546-48. Basically, lenders could charge sellers a discount (which the sellers could pass on to buyers through higher home selling price), and yet the lenders could collect full face value immediately upon default. Thus, assuming prompt reinvestment, the faster the default the greater the lender's rate of return.

Thus, notwithstanding the high-sounding and purposeful language of HUD's own guidelines stressing policies supposedly designed to preserve home ownership, in reality, HUD has thrust these low-income mortgagors into the marketplace subject only to the benevolence of "prudent" mortgagees and the state courts. Such an abdication of its responsibility is clearly inadequate....

....

HÜD has lost sight of who the Congress intended should be the beneficiaries of these low income programs. These programs were not created for the benefit of the mortgagees, although we have been constantly struck by HUD's insistence upon supporting and condoning the mortgagees' challenged practices.

Brown v. Lynn, Civil No. 73 C 334, at 27, 29 (N.D. Ill. Oct. 11, 1974) (HUD's alleged policy on $\$ \$ 235 \& 203$ foreclosures actionable under APA).

31. This is implicit in the guilty verdicts and in the heavy sentences imposed by the court in United States v. Bernstein (E.D.N.Y. July 4, 1974 [trial ended], Oct. 4, 1974 [sentences imposed]), in N.Y. Times, Oct. 5, 1974, at 35, col. 6 . According to the Ass't U.S. Att'y, many \$221(d)(2) houses were involved. Telephone Interview with Ass't U.S. Att'y Accetta, E.D.N.Y., Oct. 11, 1974. (Notes from all telephone interviews cited in this Note are on file with the Yale Law Journal.) See also Property Abandonment, supra note 2, at 861-62; Defaults Hit HUD Subsidies, Wash. Post, Mar. 16, 1974, at Al, col. 1.

32. See sources cited in note 31 supra.

33. Id.

34. See sources cited in note 2 supra.

35. Staff of House Comm. on Banking and Currency, 91st Cong., 2d Sess., Report and Recommenditions on Abuses in Federal Low- and Moderate-Income Housing ProGRAMS 4 (Comm. Print 1970) (reprinted in HUD Investigation Hearings, note 29 supra) [hereinafter cited as STAFF REPORT]. See note 61 infra.

36. Holifield Report, supra note 28 , at 16.

37. Id. at 16-17.

38. Id. at 16.

39. Id, at 17 . 
cal injuries as a result of living in their house, but other purchasers and their families were not so fortunate. One home buyer's mother allegedly died from double pneumonia resulting from the $\$ 221(\mathrm{~d})(2)$ house's lack of heat.40 Another buyer's six-month-old granddaughter died of exposure allegedly due to the repeated breakdowns of a furnace during the winter shortly after the family moved into their "rehabilitated" $\$ 235$ house.41 Still another buyer allegedly suffered blood poisoning and a serious blood clot in her leg, necessitating three weeks' hospitalization, from falling through a hole in the floor of the house's den just a few days after moving in. The hole apparently had merely been covered up in a cosmetic fashion; it had not been structurally repaired. ${ }^{42}$

In 1970, the staff of the House Committee on Banking and Currency had ominously warned that the low-income homeownership program was already "on its way toward insuring itself into a national scandal." 43 In 1972, the House Committee on Government Operations complained that

HUD, through its poor management of the mortgage insurance programs, has been unable or unwilling to control the despoilment of these housing programs by speculators and money lenders and to assure that the beneficiaries of such programs receive the protection and benefits mandated by law. ${ }^{44}$

The Committee admonished:

The time has long passed when the Federal Government, in this case HUD, can sit by relying on and trusting in fair dealings in the marketplace. ${ }^{45}$

Despite salvage attempts made from 1970 through 1973,46 the lowincome homeownership program, in the words of a special Pennsylvania task force, resulted in

the families' suffering, anguish and humiliation from having their houses collapse on them, the pain and permanent damage to the health of their children because of the lack of heat or

40. Complaint at 35, Jackson v. Romney, 355 F. Supp. 737 (D.D.C. 1973), aff'd sub nom. Jackson v. Lynn, Civil No. 73-1510 (D.C. Cir. Oct. 17, 1974).

41. Exploiting the Home-Buying Poor, supra note 2, at 525.

42. Complaint at 16, Nash v. Romney, Civil No. 72-1313-RJK (C.D. Cal. Oct. 15, 1973).

43. STAFF REPORT, supra note 35 , at 1 .

44. Holifield Report, supra note 28 , at 17 .

45. Id.

46. See Le Clercq, supra note 9, at 36.42. See generally HUD Circulars HPMC-FHA 4441.30 (Apr. 9, 1971); 4441.30A (Apr. 27, 1972); 4441.30B (Aug. 29, 1972). 
poisoning by lead-based paint, the foreclosure and subsequent eviction from their homes for failure to pay for a house that is falling apart, their financial credit permanently destroyed so that they may never be able to purchase another home, and their faith in every branch of government forever shattered because of its inaction and insensitivity. ${ }^{47}$

In early 1973, the Nixon Administration unilaterally suspended $\S 235,48$ thus provoking an intense court fight. ${ }^{49}$ Yet despite the relatively brief period in which $\S 235$ was in operation, mortgages on more than 300,000 new housing units and more than 75,000 existing housing units were insured under the program. ${ }^{50}$ Moreover, in the Housing and Community Development Act of 1974, ${ }^{51}$ Congress rejected the Nixon Administration's attempts to kill $\S 235$ permanently. 52 Although no new funds were appropriated for $\$ 235$ for Fiscal 1975,53 the Act encouraged, but did not compel, the use of existing contract authority during Fiscal 1975, ${ }^{54}$ and it extended $\S 235$ 's life through Fiscal 1976, subject to further funding. ${ }^{55}$

\section{Recovering Damages from Private Parties}

It would appear logical for these victims to seek compensation from the sellers, realtors, contractors (if the housing involved was newly constructed or rehabilitated), or mortgagees with whom they dealt. However, there are substantial obstacles to recovery against any of these private parties. Many of the sellers are poor themselves; they

47. PA. TASK Force Final Report, supra note 3, at 7.

48. 31 ConG. Q.W. REP. 40 (1973).

19. Pennsylvania v. Lynn, 501 F.2d 848 (D.C. Cir. 1974), rev'g 362 F. Supp. 1363 (D.D.C. 1973) (Sec'y of HUD has the "limited discretion" to suspend the operation of housing subsidy programs "when he has adequate reason to believe that they are not serving Congress purpose of aiding specific groups in specific ways, or are frustrating the national housing policies applicable to all housing programs").

50. Housing Production and Mortgage Credit-FHA: Home Mortgages Insured by FHA 1935-1972, 1972 HUD Statistical Yearbook 167-68 (1974) (Table 159). These figures do not include a total of more than 58,000 additional housing units insured by HUD under $\$ 235$ in 1973. 3 Biggest Cities Would Gain Under New Housing Bill, N.Y. Times, Aug. 20, 1974, at 20, col. 4, col. 8 .

51. Pub. L. No. 93-383, \$ 211, 88 Stat. 671 .

52. Section 235 would have been completely replaced under the Nixon Administration's proposals: S.2507, S.2508, 93d Cong., 2d Sess. (1974). See also Major Housing Bill to Aid Poor Approved by Senate Committee, N.Y. Times, Feb. 8, 1974, at 36, col. I.

53. See 32 CoNG. Q.W. REP. 2264 (1974).

54. Actually, in the one year following the date of enactment of the Act. Pub. L. No. 93-383, \$ 211(a)(2), 88 Stat. 671. See also Conference Report, H.R. Rep. No. 1279, 93d Cong., 2d Sess. (1974), reprinted in 120 CoNG. REc. H8058, H8098 (daily ed. Aug. 12, 1974); 32 CoNG. Q.W. Rep. 2398 (1974).

55. Pub. L. No. 93-383, § 211(a)(1), 88 Stat. 671. See also Conference Rerort, H.R. REP. No. 1279, 93d Cong, 2d Sess. (1974), reprinted in 120 CoNG. REc. H8058, H8098 (daily ed. Aug. 12, 1974); 32 Cong. Q.W. REP. 2319 (1974). 
are the previous occupants of these substandard dwellings, ${ }^{56}$ and could not pay a large judgment. Moreover, it may be hard to prove fraud since many of these sellers would not have known what was going on and may merely have been manipulated by unscrupulous realtors. ${ }^{.57}$

A large number of the other sellers are realtors who bought the properties in order to convey them at huge profits to low-income purchasers under $\S 235 .{ }^{58}$ While fraud may be present as to these sellers or realtors, in many cases they have effectively made themselves judgment proof by organizing shell corporations with no assets or by conducting business as fly-by-night operators. ${ }^{59}$ Moreover, even where there are accessible assets, it can be very difficult to prove scienter required for fraud, ${ }^{60}$ and it may take years for such cases to be resolved -much too long under these circumstances. ${ }^{61}$ And the Legal Services and Legal Aid lawyers, who typically are the only attorneys available to these low-income buyers, ${ }^{62}$ may simply lack the time and personnel to handle all of these difficult cases effectively on an individual basis. ${ }^{83}$

56. Telephone Interview with C. Edward Dilkes, Esq., formerly Legal Aid attorney for Nash (of Nash v. Romney, Civil No. 72-1313-RJK (C.D. Cal. Oct. 15, 1973)), Mar. 5, 1974 [hereinafter cited as Dilkes Interview]. (Obviously, this observation and that in the text infra, apply only to already "existing"-rather than newly-constructed-homes. As to contractors of newly-constructed homes, see p. 301 \& note 65 infra.)

57. Id.

58. Id. See also Stegman, supra note 2, at 376-77; Exploiting the Home-Buying Poor, supra note 2, at 533-34; STAFF REPORT, supra note 35, at 8.

59. Dilkes Interview, supra note 56; Telephone Interview with Stephen M. Randels, Esq., Legal Services attorney for Perry (of Perry v. Romney, Civil No. 9347 (W.D. Wash. Apr. 5, 1971), appeal dismissed as moot, 472 F.2d 565 (9th Cir. 1973)), May 2, 1973.

60. Telephone Interview with James A. Kushner, Esq., formerly Legal Aid attorncy for the Casons (of Cason v. United States, Civil Action No. 19025-2 (W.D. Mo. Apr. 5, 1973) (partial summary judgment denying damage claim), (W.D. Mo. July 8, 1974) (dismissing other claims), appeal docketed, No. 74-1672, 8th Cir. Aug. 23, 1974), May 3, 1973 [hereinafter cited as Kushner Interview]. Note that, in addition, "[t] he broker would be able to offer the FHA appraiser's report as a defense." Exploiting the Home-Buying Poor, supra note 2 , at 567 .

It should be noted that fraud cases of this sort against the realtor are occasionally won by plaintiffs: Adams v. Montgomery Real Estate \&. Co., Civil No. 71-187086-R CH (Mich. Cir. Ct. Nov. 27, 1973). But even where fraud might possibly be proved, there may be other factors, discussed in the text, preventing the successful prosecution and recovery in a fraud suit. See Exploiting the Home-Buying Poor, supra note 2, at 567.

61. Kushner Interview, supra note 60. At least, several years may be too long to wait if the family wants or needs to stay in the house-see pp. 297-98 supra-and/or if the family seeks to avoid foreclosure. For a description of the types of defects in these homes, see StAFF REPORT, supra note 35, at 3 passim. For photographs of some of these defects, see $i d$. at 113-28. See generally PA. TASK Force FINAL RePORT, supra note 3, at 5.

62. One Legal Services office approached eight private law firms in hopes of getting them to handle such cases on a referral basis. It was remarkably unsuccessful, because the firms considered these sorts of cases to demand excessive amounts of legal research, investigation, documentation, discovery, pre-trial preparation, and trial time. Plaintiffs' Brief in Opposition to Defendants' Motion for Judgment on the Pleadings at $8 \mathrm{n} .7$, Massey v. Lynn, Civil No. 39822 (E.D. Mich. June 27, 1974), appeal docketed, No. 74-2122, 6th Cir., Oct. 14, 1974.

63. Telephone Interview with George D. Gould, Esq., Iegal Services attorney for Davis (of Davis v. Romney, 355 F. Supp. 29 (E.D. Pa. 1973), aff'd in part and vacated and remanded in part, 490 F.2d 1360 (3d Cir. 1974)) May 1, 1973. See also note 62 supra. 
In addition, the neighborhoods involved tend to have high resident turnover, making it hard to locate witnesses, and white neighbors may be disinclined to testify on behalf of poor blacks who have just moved into their neighborhoods. ${ }^{04}$ Similar problems exist as to the contractors. $^{65}$

Mortgagees are less likely to make undercapitalized or judgment proof defendants. ${ }^{66}$ Many of them have insured a large number of properties ${ }^{67}$-and profited handsomely upon foreclosure. ${ }^{88}$ However, the difficulty in proving scienter and the problem of limited legal services remain..$^{69}$ Other possible obstacles lie in lack of privity under local contract larw ${ }^{70}$ and lack of sufficient duty under local tort law. ${ }^{71}$

Therefore, some suits against private defendants may result in effective relief. But the many problems described, as well as the common element linking the cases-the role of the FHA-make the United States government an attractive (even if not the only possible) defendant. Recent low-income homeownership plaintiffs have pursued a variety of claims in their quest for effective compensation.

\section{Relief under the Administrative Procedure Act}

Purchasers might seek a form of relief by invoking judicial review of FHA's activities under the Administrative Procedure Act (APA). ${ }^{72}$

64. Kushner Interview, supra note 60 .

65. Telephone Interview with Stanton J. Price, Esq., formerly attorney for Nash (of Nash v. Romney, Civil No. 72-1313-RJK (C.D. Cal. Oct. 15, 1973)), Mar. 5, 1974. See Comment, Liability of the Institutional Lender for Structural Defects in New Housing, 35 U. CHI. L. REv. 739, 740 (1968) [hereinafter cited as Lender Liability].

66. The FHA has standards for approving mortgagees, including capital requirements: 24 C.F.R. $\$ \$ 203.1-203.9$ (1974).

67. Holifield Report, supra note 28, at 18-19.

68. See note 30 supra.

69. See pp. $300 \cdot 01$ supra.

70. That is, lack of privity between the mortgagee and the seller in the buy-sell contract between the seller and the plaintiff-buyer. See Jeminson v. Montgomery Real Estate \& Co., 47 Mich. App. 731, 210 N.W.2d 10, leave to appeal granted, 390 Mich. 788 (1973).

71. See id. But see Conner v. Great W. Sav. \& Loan Ass'n, 69 Cal. 2d 850, 477 P.2d 609, 73 Cal. Rptr. 369 (1968) (which may have been partially overruled by CAL. Civ. Code $\$ 3434$ (West 1970)); Morrocco v. Felton, 112 N.J. Super. 226, 270 A.2d 739 (1970). For a discussion of possible causes of action by buyers of new homes against institutional construction lenders, see Lender Liability, supra note 65, at 755.60.

72. 5 U.S.C. $\$ \$ 701-06$ (1970). The APA provides, id. \$ 702, that “[a] person suffering legal wrong because of agency action, or adversely affected or aggrieved by agency action within the meaning of a relevant statute, is entitled to judicial review thereof." It also, $i d$. $\$ 706$, gives to the reviewing court the power to "(1) compel agency action unlawfully withheld or unreasonably delayed; and (2) hold unlawful and set aside agency action, findings, and conclusions found to be-(A) arbitrary, capricious, an abuse of discretion, or otherwise not in accordance with law...(D) without observance of procedure required by law...." 
It appears that purchasers have standing to bring such suits, ${ }^{73}$ and it may be that significant equitable relief is available under the APA, ${ }^{74}$ although this is far from certain..$^{75}$ But even if the APA can give rise to equitable relief, the APA apparently does not by itself give courts the power to award damages ${ }^{76}$ against the government, ${ }^{77}$ and injunctive or mandamus relief cannot provide compensation for pain and suffering, physical injuries, ${ }^{78}$ or ruined credit ratings, ${ }^{79}$ which

73. Arnold Tours, Inc. v. Camp, 400 U.S. 45 (1970); Association of Data Processing Serv. Orgs., Inc. v. Camp, 397 U.S. 150 (1970); Barlow v. Collins, 397 U.S. 159 (1970). Lowincome homeownership plaintiffs were held to have APA standing in Davis v. Romney, 355 F. Supp. 29, 38 (E.D. Pa. 1973), aff'd on this issue, 490 F.2d 1360, 1363-64 (3d Cir. 1974); cf. Jackson v. Romney, 355 F. Supp. 737, 741 (1973) (no standing under APA), aff'd on other grounds sub nom. Jackson v. Lynn, No. 73-1510 at 3, 7-8 (D.C. Cir. Oct. 17, 1974).

74. Plaintiffs in Davis v. Romney, $490 \mathrm{~F} .2 \mathrm{~d} 1360,1370$ \& n.5 (3d Cir. 1974), aff'g in part and vacating and remanding in part 355 F. Supp. 29, 33, 45 (E.D. Pa. 1973), apparently have won the right to some sort of injunction, and they are seeking very broad relief on the remand, including (1) having HUD make or reimburse homeowners for whatever repairs are necessary to bring every subcode $\$ \$ 235$ or 221(d)(2) existing-houseprogram property bought in Philadelphia since January 1, 1968, up to code standards; (2) requiring HUD to make "every attempt possible"-including "periodic notices over sustained periods of time in the newspapers, radio and television"-to locate the people who bought and vacated such sub-code properties, in order (3) to offer to them-at no more than what they paid on their original property, with no down payment, and with full credit for amounts paid on the mortgages of their original properties-houses that HUD has acquired through foreclosure or otherwise; (4) having HUD provide adequate moving expenses to these people plus having HUD take "all necessary steps to insure that thesc people shall not have their credit impaired in any way"; and (5) having the court appoint a master to oversee, review, and implement this order. Plaintiffs' Mlemorandum of Law in Support of Proposed Order for Relief at 3-5, Davis v. Romney, [on remand, as] Civil No. 71-198 (1974).

75. The court in Jackson v. Lynn, Civil No. 73-1510 at 7-8 (D.C. Cir. Oct. 17, 1974) dismissed an APA claim for injunctive relief because of the plaintiffs' failure to allege or demonstrate that the desired action was previously requested of, and denied by, HUD. While the court said that the corrective administrative action sought, which could result in the plaintiffs" acquisition of homes other than their present defective ones, "[a]rguably ... might be considered ...., viewed as judicial review under section 10(a) of the [APA], of 'agency action' violative of section 221(d)(2) that has injured the plaintiffs," id. at 7, the short shrift given to the plaintiffs' other claims, for Tucker Act and declaratory relief, may suggest that the court would not have been any more favorably disposed to the $A P A$ claim even if the plaintiffs had shown a prior request and denial. Viewed in this light, the comment of the Davis court that it was remanding "so that, if possible, an injunction" may issue more narrowly drawn to meet the needs of this case," Davis v. Romney, 490 F.2d 1360, 1370 (1974) (emphasis added), may indicate that the Davis plaintiff' hopes on remand, supra note 74, are unlikely to be realized. This is certainly the view of Cason v. United States, Civil No. 19025-2, at 9-10 (W.D. Mo. July 8, 1974).

76. "[A]t common law there could be no damages in a mandamus proceeding." Annot., 73 A.L.R.2d 903, $\$ 1(1960)$. "[I]n many jurisdictions in the United States, statutes permit the award or recovery of damages in a mandamus proceeding." Id. $\$ 2$ [a]. The APA says nothing about damages being permitted under it.

77. Although 5 U.S.C. $\$ 706(1)(1970)$ might be viewed as giving the courts the power to compel action which would involve the expenditure of some funds by the United States-see Davis v. Romney, 490 F.2d 1360, 1369-70 (3d Cir. 1974)-the Supreme Court has said that the APA is not "to be deemed an implied waiver of all governmental immunity from suit," Blackmar v. Guerre, 342 U.S. 512, 516 (1952) (dictum). Even those circuits which have said that the APA is a complete waiver of sovereign immunity (see Littell v. Morton, 445 F.2d 1207, 1212-14 (4th Cir. 1971)) have not actually had any cases where they wound up ordering the government to pay compensatory damages.

78. See pp. 298, 299 supra, as to pain and suffering and physical injuries.

79. As to effect on credit ratings and future ability to buy decent homes, see Abuses, supra note 2 , at 471 . 
are real injuries that the low-income homeownership victims have suffered.

\section{Relief under $\$ 518$ of the National Housing Act}

Perhaps because of the inadequacies of suits against private parties and of actions under the APA, Congress in late $1970^{80}$ enacted $\S 518(\mathrm{~b})^{81}$ of the National Housing Act, authorizing the Secretary of HUD "to make expenditures to correct, or to compensate the owner for, structural or other defects which seriously affect the use and livability of any single-family dwelling which is covered by a mortgage insured under [ $\$ 235$ only] ... ." Under $\$ 518(c),{ }^{82}$ the Secretary was directed to promulgate regulations to "prescribe the terms and conditions under which expenditures and payments may be made under the provisions of $[\$ 518(\mathrm{~b})] \ldots$. Three months passed ${ }^{83}$ before regulations were issued, and the regulations that finally appeared adopted as a test for determining whether $\S 518(\mathrm{~b})$ assistance would be granted to particular applicants

[t]he extent to which the defects represent a clear and present danger to the health and safety of the occupants $\ldots . .^{84}$

It is unclear why HUD chose to employ such a narrow requirement, and it was promptly and successfully challenged in court. ${ }^{85}$ HUD

80. Act of Dec. 31, 1970, Pub. L. No. 91-609, § 104, 84 Stat. 1771.

81. 12 U S C. $\$ 1735 \mathrm{~b}(\mathrm{~b})(1970)$, amended by Pub. L. No. 93-383, $\$ 306,88$ Stat. 678 . The pre-1974 version is used here, for discussion purposes. Changes are discussed in pp. 305,306 infra. Note that this section covers "existing homes"-which is where the most serious problems had been discovered. See Le Clercq, supra note 9 , at $32 \& 44$. Section 518(a)-12 U.S.C. $\$ 1735 \mathrm{~b}(\mathrm{a})$ (1970)-covers new hotsing, and had been enacted as Act of Sept. 2, 1964, Pub. L. No. 88-560, $\$ 121,78$ Stat. 783 (and amended slightly in 1967).

82. 12 U.S.C. $\$ 1735 b(c)(1970)$. This section was enacted along with $\$ 518(a)$. See note 81 supra. It has not been altered by Pub. L. No. 93-383, 88 Stat. 633 .

83. Until April 9, 1971, when HUD Circular HPMC.FHA 4441.30 (Apr. 9, 1971) was promulgated.

84. The regulations adopted as additional tests "(b) [t] the availability of funds from which the Secretary is authorized to make expenditures hereunder; and (c) [s]uch other matters as he deems material." 24 C.F.R. $\$ 200.527$ (1974).

85. Bailey v. Romney, 359 F. Supp. 596, 601 (D.D.C. 1973), government's appeal dismissed per stipulation, No. 73-2036 (D.C. Cir. Jan. 11, 1974), plaintiffs' appeal docketed, No. 73-2007, D.C. Cir., July 25, 1973. The court rejected not only HUD's $\$ 518(\mathrm{~b})$ test, but also the plaintiffs' suggested $\$ 518(\mathrm{~b})$ test-i.e., that reimbursement should be due for all defects which are in violation of the local codes: The court held that the test required by the statute was whether the defects "seriously affect the use and livability of the home"-quoting the statutory language. $359 \mathrm{~F}$. Supp. at 601-02. But see note .96 infra (1974 change in this statutory language).

The court preliminarily enjoined the Secretary of HUD from applying the "clear and present danger" standard, directed application of the "serious effect on the use or livability" standard, and remanded the plaintiffs' applications for reimbursement under $\$ 518(\mathrm{~b})$ to the Secretary for evaluation in light of this standard. $359 \mathrm{~F}$. Supp. at 601-02. Now almost two years later, most of the Bailey plaintiffs are still awaiting relief. Accord- 
then issued a second ${ }^{86}$ and finally a third ${ }^{87}$ set of rules for administering $\S 518(\mathrm{~b})$. However, HUD has been severely criticized for failing to follow even these, its own regulations, ${ }^{88}$ and $\S 518(\mathrm{~b})$ itself has been attacked as not providing sufficient protection ${ }^{89}$ or relief ${ }^{90}$ for the $\$ 235$ victims. Moreover, $\S 518(\mathrm{~b})$ was not available to $\$ 22 \mathrm{l}(\mathrm{d})(2)$ and $\$ 203$ participants even though they may have suffered the same

ing to Roger Wolf, Legal Services attorney for Bailey, Bailey was a "paper victory" which to date "hasn't helped the clients much." Telephone Interview, October 11, 1974. The Bailey court refused to certify the action as a class action, and held that HUD was not required to provide an adjudicatory hearing for determination of eligibility for $\$ 518(\mathrm{~b})$ reimbursement. 359 F. Supp. at 602-03.

86. HUD Circular HPMC-FHA 4441.30A (Apr. 27, 1972). This circular was issued while Bailey v. Romney, 359 F. Supp. 596 (D.D.C. 1973), was still pending-and presumably at least in part because of the pendency of the case.

87. HUD Circular HPMC-FHA 4441.30B (Aug. 29, 1972). Interestingly, the original "clear and present danger" test was retained in 24 C.F.R. $\$ 200.527$ (1974). Thus, if Bailey v. Romney, 359 F. Supp. 596 (D.D.C. 1973), was correct about those original regulations being out of harmony with the statute under which they were issued, then presumably those regulations became "a mere nullity." Manhattan Gen. Equip. Co. v. Commissioner, 297 U.S. 129, 134 (1936). Note that the governing statute has now been changed to require a test similar to the one rejected as not permissible under the prior statute. Pub. L. No. 93-383, \& 306,88 Stat. 678 .

88. Indeed, HUD has been sued for failing to comply with those regulations that HUD has itself chosen to issue. See LaCount v. Romney, Civil No. 72-2082 (E.D. Pa., filed Oct. 25, 1971). It is alleged there, for example, that although HUD-after over a year of delay-notified named plaintiff Woolfolk that it had determined that it would repair under $\$ 518(\mathrm{~b})$ some 36 items that it had determined under the regulations to be serious enough, "[d] espite numerous phone calls and letters as to the condition of her property almost no work took place on her property for the next ten months." Plaintiffs' Memorandum of Law in Opposition to Defendants' Motion to Dismiss at 7 (Apr. 30, 1973).

According to the attorney for Nash (of Nash v. Romney, Civil No. 72-1313-RJK (C.D. Cal. Oct. 15, 1973)), HUD has "made absolutely no effort to make $\$$ 518(b) work." Dilkes Interview, supra note 56. Other attorneys from around the country have expressed similar sentiments: Telephone Interview with G. Dan Bowling, Esq., attorney for Jackson (of Jackson v. Romney, 355 F. Supp. 737 (D.D.C. 1973), aff'd sub nom. Jackson v. Lynn, Civil No. 73-1510 (D.C. Cir. Oct. 17, 1974)), Aug. 20, 1973; Telephone Interview with Roger Wolf, Esq., Legal Services attorney for Bailey (of Bailey v. Romney, 359 F. Supp. 596 (D.D.C. 1973), government's appeal dismissed per stipulation, Civil No. 73-2036 (D.C. Cir. Jan. 11, 1974), plaintiffs' appeal docketed, Civil No. 73-2007, D.C. Cir. July 25, 1973), Sept. 4, 1973; Telephone Interview with Jerome Riffel, Esq., Lcgal Aid attorney for the Casons (of Cason v. United States, Civil No. 19025-2 (W.D. Mo. Apr. 5, 1973) (partial summary judgment denying damage claim), (W.D. Mo. July 8, 1974) (dismissing other claims), appeal docketed, Civil No. 74-1672, 8th Cir., Aug. 23, 1974), March 1, 1974. It is true that HUD has done some adequate and prompt repairs under $\$ 518(\mathrm{~b})$-particularly after having been sued or threatened with suit: Telephone Interview with Attorney Randels, supra note 59, Mar. 1, 1974.

89. Plaintiffs' Brief, supra note 62, at 9-10, Massey v. Lynn, Civil No. 39822 (E.D. Mich. June 27, 1974), appeal docketed, Civil No. 74-2122, 6th Cir., Oct. 14, 1974; Complaint at 13, Nash v. Romney, Civil No. 72-1313-RJK (C.D. Cal. Oct. 15, 1973). Among the procedural complaints about $\$ 518(\mathrm{~b})$ are that it leaves the determination of defects up to the very agency that failed to spot them initially; that it does not require an adjudicatory hearing; that it leaves compensation-even where HUD finds that there are $\$ 518(\mathrm{~b})$-eligible defects-discretionary rather than making it mandatory; and that $\$$ 518(c), 12 U.S.C. $\$ 1735 \mathrm{~b}(\mathrm{c})$ (1970), forbids judicial review of HUD's determinations under $\S 518(\mathrm{~b})$.

90. One such complaint is that $\$ 235$ requires that there be no code violations when the mortgage insurance is approved, and yet $\$ 518(\mathrm{~b})$ allows compensation only for defects that "seriously affect the use and livability" of the house. The court in Bailey v. Romney, 359 F. Supp. 596, 602 (D.D.C. 1973), found these to be different standards. See also Plaintiffs' Brief, supra note 62, at 10, Massey v. Lynn, Civil No. 39822 (E.D. Mich. June 27, 1974), appeal docketed, Civil No. 74-2122, 6th Cir., Oct. 14, 1974. 
types of harm that prompted Congress to enact $\S 518(\mathrm{~b})$ for $\S 235$ victims. ${ }^{n 1}$ Indeed, several congressmen considered the deficiencies of $\S 518(\mathrm{~b})$ and HUD's performance under $\S 518(\mathrm{~b})$ to be so glaring that bills to amend $\S 518(\mathrm{~b})$ were introduced little more than a year after its enactment, ${ }^{92}$ and they were followed by others..$^{93}$

Section 518(b) finally was amended, by the Housing and Community Development Act of $1974,{ }^{94}$ but the standard for relief is even more restrictive than before. Although it properly extends $\S 518$ (b)'s coverage to certain $\S 203$ and $\S 221$ homeowners, ${ }^{95}$ the amended section adopts a modified form ${ }^{98}$ of the "clear and present danger" test that was unsuccessfully embodied in HUD's first regulations under the original $\S 518(b) .{ }^{97}$ It thus leaves $\S 235$ homeowners worse off than before.

The major deficiencies that have not been ameliorated by the 1974 amendments comprise a long list. Even the new $\$ 518(\mathrm{~b})$ fails to require-not just authorize-HUD to make reimbursements where the statutory conditions for them are met, nor does it require that the payments be made promptly or within a specified time limit. ${ }^{98}$ It leaves standing the $\S 518$ (c) bar to judicial review of the determinations $^{00}$ which are, after all, being made by the very agency accused of being at fault in allowing such substandard houses to be approved for insurance in the first place. It does not require HUD to take all steps necessary to notify owners of the availability of such relief, ${ }^{100}$ nor does it shift the burden of proving discoverability of the defects as of the date of the issuance of the insurance commitment from

91. See H.R. REP. No. 417, 93d Cong., Ist Sess. 4 (1973). Note the change discussed in text infra (1974 change).

92. S.3248, 92d Cong., 2d Sess. $\$ 704$ (1972); S.3892, 92d Cong., 2d Sess. (1972); H.R. 14754, 92d Cong., 2d Sess. (1972); H.R. 16704, 92d Cong., 2d Sess. $\$ 7$ (c) (1972).

93. S.3066, 93d Cong.; 2d Sess. \$ 107 (1974); S.855, 93d Cong,, 1st Sess. (1973); H.R.J. Res, 512, 93d Cong., 1st Sess. \$ 14(a) (1973).

94. Pub. L. No. 93-383, $\$ 306,88$ Stat. 678.

95. Id. As amended, $\$ 518(\mathrm{~b})$ covers not only $\S 235$ existing-home homeowners, but also those $\$ \$ 203$ and 221 homeowners whose existing homes are "located in an older, declining urban area." Presumably, this neighborhood requirement relates to $\$ 223(e)$ of the Act, 12 U.S.C. $\$ 1715 n(e)(1970)$.

96. "The Secretary is anthorized to make expenditures to correct, or to reimburse the owner for the corrections of, structural or other major defects which so seriously affect use and livability as to create a serious danger to the life or safety of inhabitants of [the covered dwellings] ...." (Emphasis added.)

97. See p. 303 supra.

98. Both would have been required under the original version of S.3066, 93d Cong., 2d Sess. $\$ 107$ (1974). For the scope of the problem, see note 88 supra.

99. Review would have been permitted in the original version of S.3066, 93d Cong., 2d Sess., $\$ 107$ (1974).

100. This is a serious problem. Empirical Study, note 3 supra, at 800 n.70. Such notification would have been required under the original version of S.3066, 93d Cong., $2 \mathrm{~d}$ Sess. $\$ 107$ (1974). 
the homeowner to HUD.101 It fails to require an adjudicatory hearing, ${ }^{102}$ and it does not provide compensation for all deviations from code compliance. ${ }^{103}$ Moreover, whereas the original language of $\S 518(b)^{104}$ could at least arguably be taken to permit compensation for consequential-but very real-harms resulting from structural defects of the house, ${ }^{105}$ the new language makes clear that such compensation is unavailable. ${ }^{106}$

\section{Suing the United States for Damages under the Tucker Act}

Due to the shortcomings of private, administrative, and legislative remedies, several suits ${ }^{107}$ have been brought against the federal government for damages under the Tucker Act. ${ }^{108}$ That statute gives jurisdiction to the federal Court of Claims ${ }^{109}$ and concurrently, for claims not exceeding $\$ 10,000$, to the U.S. district courts"10 over "any claim against the United States founded either upon the Constitution or any Act of Congress, or any regulation of an executive department, or upon any express or implied contract with the United States ....."111

101. This might have been accomplished under the original version of S.3066, 93d Cong., 2d Sess. $\$ 107$ (1974).

102. This is particularly important since the very agency that allowed such homes to be FHA-insured is the agency determining whether or not the purported defects are ones that-to quote $\$ 518(\mathrm{~b})$ - "a proper inspection could reasonably be expected to disclose" (as of the date of issuance of the insurance commitment).

103. See pp. 308-09 infra.

104. The statute authorized

expenditures to correct, or to compensate the owner for, structural or other defects which seriously affect the use and livability.... (Emphasis added.)

105. For examples, see pp. 298, 299 supra.

106. It authorizes compensation only

to correct, or to reimburse the owner for the correction of, structural or other major defects which so seriously affect use and livability as to create a serious danger to the life or safety of inhabitants . . . (Emphasis added.)

107. Davis v. Romney, 355 F. Supp. 29 (E.D. Pa. 1973), aff'd in part and vacated and remanded in part, 490 F.2d 1360 (3d Cir. 1974); Perry v. Romney, Civil No. 9347 (W.D. Wash. Apr. 5, 1971), appeal dismissed as moot, 472 F.2d 565 (9th Cir. 1973); Cason v. United States, Civil No. 19025-2 (W.D. Mo. Apr. 5, 1973) (partial summary judgment denying damage claim), (W.D. Mo. July 8, 1974) (dismissing other claims), appeal docketed, Civil No. 74-1672, 8th Cir., Aug. 23, 1974; Massey v. Lynn, Civil No. 39822 (E.D. Mich. June 27, 1974), appeal docketed, Civil No. 74-2122, 6th Cir., Oct. 14, 1974; Nash v. Romney, Civil No. 72-1313-RJK (C.D. Cal. Oct. 15, 1973); Jackson v. Romney, 355 F. Supp. 737 (D.D.C. 1973), aff'd sub nom. Jackson v. Lynn, Civil No. 73-1510 (D.C. Cir. Oct. 17, 1974); Williams v. United States, Civil No. KC-3346 (D. Kan., filed June 8, 1971); Brown v. United States, Civil No. 18943-2 (W.D. Mo., filed Dec. 23, 1970), dismissed without prejudice (Apr. 1, 1971).

108. 28 U.S.C. $\$ \$ 1346(a)(2), 1491$ (1970).

109. Id. $\$ 1491$.

110. Id. $\$ 1346(\mathrm{a})(2)$.

111. Id. § 1491 . 


\section{A. Constitutional Claims}

At least one of the recent cases ${ }^{112}$ alleges that the operation of $\S 235$ has deprived plaintiffs of property without just compensation, creating a claim founded on the Fifth Amendment to the Constitution. ${ }^{113}$ The weakness of this approach is that the Fifth Amendment by its terms applies only to "private property taken for public use,"114 and it is difficult to fit the present problem into that framework. There is no property of the plaintiffs that the United States or the general public has come to possess or use. ${ }^{115}$ And while it might be argued that the U.S. has "taken" the plaintiffs" former good credit rating or previous decent housing, these are at best consequential rather than direct effects of the governmental action. It has long been held that where the injury is not direct but is merely consequential or incidental, the governmental action is not a "taking" in the constitutional sense. ${ }^{116}$

\section{B. Statutory Claims}

Several suits ${ }^{117}$ have been brought on the theory that the victims have a Tucker Act claim founded upon an Act of Congress. They point out that although $\$ \S 235$ and 221 (d)(2) do not give directly to low-income home buyers any right to damages or indeed by terms any other rights, ${ }^{118}$ they do provide that

112. Brown v. United States, Civil No. $18943-2$ (W.D. Mo., filed Dec. 23, 1970), dismissed without prejudice (Apr. 1, 1971).

113. "[N]or shall private property be taken for public use, without just compensation." U.S. CoNST. amend. V. Such an inverse eminent domain claim seems to be the only type of "claim founded upon the Constitution" that can be brought under the Tucker Act. See Developments in the Law-Remedies Against the United States and its Officials, 70 HARv. L. REv. 827, 876-81 (1957) [hereinafter cited as Developments].

114. (Emphasis added.)

115. See p. 314 infra, as to the mortgage insurance premium.

116. Omnia Commercial Co. v. United States, 26I U.S. 502, 510 (1923); Keokuk \& Hamilton Bridge Co. v. United States, 260 U.S. 125 (1922); Bedford v. United States, 192 U.S. 217 (1904).

117. Davis v. Romney, 355 F. Supp. 29 (E.D. Pa. 1973), aff'd in part and vacated and remanded in part, 490 F.2d 1360 (3d Cir. 1974); Perry v. Romney, Civil No. 9347 (W.D. Wash. Apr. 5, 1971), appeal dismissed as moot, $472 \mathrm{~F} .2 \mathrm{~d} 565$ (9th Cir. 1973); Massey v. Lynn, Civil No. 39822 (E.D. Mich. June 27, 1974), appeal dockeled, Civil No. 74-2122, 6th Cir. Oct. 14, 1974; Nash v. Romney, Civil No. 72-1313-RJK (C.D. Cal. Oct. 15, 1973); Jackson v. Romney, 355 F. Supp. 737 (D.D.C. 1973), aff'd sub nom. Jackson v. Lynn, Civil No. 73-1510 (D.C. Cir. Oct. 17, 1974); Williams v. United States, Civil No. KC-3346 (D. Kan., filed June 8, 1971); Brown v. United States, Civil No. 18943-2 (W.D. Mo., filed Dec. 23, 1970), dismissed without prejudice (Apr. 1, 1971).

118. For example, the crucial $\$ 221(\mathrm{~d})(2)$-which establishes the code-compliance requirement (quoted in text infra)-is worded in terms of eligibility of mortgages for insurance and is located "as part of a section regulating loan ratios and maximum property value insurable, and permitting other financial restrictions to be imposed as prerequisites to mortgage insurance." Davis v. Romney, 490 F.2d 1360, 1372 (3d Cir. 1974). Section 22l(d)(2) does not talk in terms of low-income home buyers' rights. 
[t]o be eligible for insurance under [these] section[s], a mortgage shall be secured by property upon which there is located a dwelling conforming to applicable standards prescribed by the Secretary under $[\$ 221(\mathfrak{f})]$, and meeting the requirements of all State laws, or local ordinances and regulations, relating to the public health or safety, zoning, or otherwise, which may be applicable thereto .....119

Plaintiffs argue ${ }^{120}$ that this gives to home buyers under $\S \S 235$ or $221(\mathrm{~d})(2)$ the right to houses complying with all local codes, and that their demands for damages to compensate for denials of this right thus are claims founded upon an Act of Congress.

The government has repeatedly ${ }^{121}$ argued that this language does not mandate that the FHA withhold mortgage insurance on homes that do not comply with local codes, noting ${ }^{122}$ that $\$ 221(\mathrm{f})^{123}$ provides that " $[t]$ he property . . . shall comply with such standards and conditions as the Secretary [of HUD] may prescribe to establish the acceptability of such property for mortgage insurance ...." The government also makes a policy argument ${ }^{124}$ that it would be administratively burdensome for HUD to learn and seek compliance with all of the local housing and building codes around the nation. Such a burden, it is argued, could retard HUD's achievement of Congress' stated goal of promoting more homeownership and better housing for as many of the poor as possible.

In making this argument, however, the government ignores the

119. 12 U.S.C. $\S 1715 l(\mathrm{~d})(2)(1970)$, incorporated into $\S 235$ by 12 U.S.C. $\S 1715 z(\mathrm{i})(2)$ (1970).

120. See, e.g., Davis v. Romney, 355 F. Supp. 29, 44-48 (E.D. Pa. 1973).

121. See, e.g., id. at 44-45, aff'd, 490 F.2d at 1367-68. See also Defendants' Answers to Plaintiffs' First Set of Interrogatories to Defendant Raymond Carrasco at 2, Nash v. Romney, Civil No. 72-1313-RJK (C.D. Cal. Oct. 15, 1973): "There is no statutory obligation on the part of HUD to inspect homes for compliance with local codes. Such an inspection would not be feasible because of the magnitude of work involved and the great variety of code provisions that exist within the thousands of cities and counties in the nation in which Sections 221(d)(2) and 235 insured housing is located." See also Appellees' Brief on Appeal at 28-29, Perry v. Romney, Civil No. 9347 (W.D. Wash. Apr. 5, 1971), appeal dismissed as moot, 472 F.2d 565 (9th Cir. 1973):

The Secretary of Housing and Urban Development has promulgated an exhaustive set of uniform minimum standards of habitability with which all Federal Housing Administration appraisers are commanded to comply. These standards are sometimes above and sometimes below local codes.... It would be unreasonable, if not impossible, for FHA appraisers to become knowledgeable about the codes of every county and town in which they make appraisals. Such an order would certainly diminish the effectiveness of the Housing Act and thereby thwart the intent of Congress. (Emphasis added.)

122. HUD made this argument in Davis v. Romney, 355 F. Supp. 29, 40 (E.D. Pa. 1973), even though, to the court's confusion, HUD did not cite $\S 221(\mathrm{f})$ as such.

123. 12 U.S.C. $\$ 1715 l(\mathrm{f})(1970)$.

124. See sources cited in note 121 supra. 
fact that the statute does not make meeting the Secretary's standards an alternative to code compliance. Instead, $\$ \S 221(\mathrm{~d})(2)$ and $235^{125}$ require ${ }^{126}$ not only that the properties meet the Secretary's standards but also that the properties meet "the requirements of all State laws, or local ordinances and regulations, relating to the public health or safety, zoning, or otherwise, which may be applicable thereto . . . ." The courts thus far have rejected the government's statutory construction of the code-compliance provisions. ${ }^{127}$

The government has also argued that the courts lack jurisdiction over these plaintiffs' claims under the Tucker Act and that the plaintiffs have no claim upon which relief may be granted under the Tucker Act, because (a) the code-compliance requirement does not give rise to any right or claim in the plaintiffs, ${ }^{128}$ and (b) the Tucker Act covers only claims for money that the government has wrongfully received and retained or that the government is required under explicit statutory language to pay over to the plaintiffs. ${ }^{129}$ So far these contentions have carried the day for the government. ${ }^{130}$

As to the first contention, the code-compliance provision was enacted as part of the Housing Act of $1959,{ }^{131}$ and the legislative history of that Act is silent on whether or not the provision was intended

125. See note 119 supra.

126. "To be eligible for insurance under this section, a mortgage shall be secured by property upon which there is located a dwelling conforming to the applicable standards prescribed by the Secretary under [\$ 221(f)], and meeting the requirements of all State laws, or local ordinances and regulations, relating to the public health or safety, zoning, or otherwise, which may be applicable thereto . . .." (Emphasis added.)

127. The district court's response in Davis v. Romney, 355 F. Supp. 29, 44 (E.D. Pa. 1973), aff'd on this issue, 490 F.2d 1360, 1367-68 (3d Cir. 1974), was that

Congress in its wisdom has mandated that defendants follow certain procedures in carrying out the 22I(d)(2) and 235 Existing House Programs. If the defendants feel that they are unworkable it is incumbent upon them to go to Congress for a change in

the law.... If more money is needed to finance these programs they should appeal to the conscience of the government and the nation.

(Note, however, that because the district court had failed to determine under FED. $R$. Civ. P. 23(c) that the suit was a class action or to define the class, the injunction granted by the district court is vacated and the case remanded for a narrower injunction. 490 F.2d at 1366, 1370. Presumably it should be no problem to get such class relief if the proper technicalities are followed, given the rest of the Third Circuit's opinion on this issue.)

128. See Appellees' Brief on Appeal at 19, 25, Perry v. Romney, Civil No. 9347 (W.D. Wash. Apr. 5, 1971), appeal dismissed as moot, 472 F.2d 565 (9th Cir. 1973): "[T]he National Housing Act does not create a duty running to the Purchasers."

129. See, e.g., Davis v. Romney, 490 F.2d 1360, 1371 (3d Cir. 1974).

130. Davis v. Romney, 355 F. Supp. 29, 46-48 (E.D. Pa. 1973) (dismissing the Tucker Act claim on ground (b)), aff'd on ground (a), 490 F.2d 1360, 1371-72 (3d Cir. 1974); Nash v. Romney, Civil No. 72-1313-RJK, at 10-11 (C.D. Cal. Oct. 15, 1973) (quoting the Davis district court with approval); Jackson v. Romney, 355 F. Supp. 737, 739-41 (D.D.C. 1973), aff'd sub nom. Jackson v. Lynn, Civil No. 73-1510, at 4-7 (D.C. Cir. Oct. 17, 1974).

131. Act of Sept. 23, 1959, Pub. L. No. 86-372, 73 Stat. 654. The code-compliance provision was $\S 110(\mathrm{~b}), 73$ Stat. 659 . 
to create rights in, or to protect, the home buyers under these programs. ${ }^{132}$ The government has argued ${ }^{133}$ that the only purpose of the requirement was to protect the government in the event that a mortgagor under these programs defaulted and the government had to pay off the insured mortgage and then try to recoup its expenses by selling the foreclosed house. The government can also point out that even under $\S 203$, the original FHA mortgage insurance program (for middle-income and upper-income purchasers), ${ }^{134}$ the government has long been required ${ }^{135}$ to appraise the houses before insuring a mortgage and to communicate this appraised value to the home buyers, and yet the Supreme Court in United States $v$. Neustadt ${ }^{136}$ held that "there is no legal relationship between the FHA and the individual mortgagor." 137

The legislative history of $\$ 203$ should not, however, be applied automatically to $\$ \$ 235$ and 221 (d)(2). Although the 1959 legislative history is silent, there is plenty of prior and subsequent legislative history from which such an intent can be discerned. ${ }^{138}$ Much of this derives from Congress' consideration of the Housing Act of 1958, where the code-compliance requirement was first proposed. That Act failed to pass before the session ended, but its new code-compliance requirement was adopted as part of the 1959 Act. ${ }^{139}$ There are solid grounds for arguing that the code-compliance requirement, which had not been enacted when the Neustadts bought their house, ${ }^{140}$ is different in kind from the appraisal requirement, and that the history and intent behind $\S \S 235$ and $221(\mathrm{~d})(2)$ are different from those

132. S. REP. No. 924, 86th Cong., Ist Sess. 13 (1959), says merely that $\$ 110$ (b) "[a]mends section 221(d) to increase the maximum mortgage amount for a single-family residence from $\$ 10,000$ to $\$ 12,000$ in high-cost areas. Makes eligible for mortgage insurance 2-, 3-, and 4-family dwellings which meet FHA minimum property standards and appropriate State and local housing ordinances or regulations." Apparently this is the only congressional report dealing with $\S 110$ (b) of the 1959 Act: Jackson v. Romney, $355 \mathrm{~F}$. Supp. 737, 743 n.14 (D.D.C. 1973), aff'd sub nom. Jackson v. Lynn, Civil No. 73-1510 (D.C. Cir. Oct. $17,1974)$.

133. See, e.g., Davis v. Romney, 490 F.2d 1360, 1372 (3d Cir. 1974).

134. Originally enacted as Act of June 27, 1934, ch. $847, \S 203,48$ Stat. 1248.

135. Under $\$ 226 ; 12$ U.S.C. $\$ 1715 q$ (1970), originally enacted as Act of Aug. 2, 1954, ch. $649, \$ 126,68$ Stat. 607 .

136. 366 U.S. $696(1961)$. This case is more fully analyzed at p. 316 infra.

137. 366 U.S. at 709, quoting as dispositive H.R. REP. No. 2271, 83d Cong., 2d Sess. 66-67 (1954) (conference report). But see note 202, infra.

138. See the analysis of the 1958 legislative history in Le Clercq, supra note 9, at 33-35 n.114. For prior and subsequent legislative history of $\$ \S 221(\mathrm{~d})(2)$ and 235 , see sources cited in note 141 infra. The history found unconvincing in Jackson v. Lynn, Civil No. 73-1510, at 5-6 (D.C. Cir. Oct. 17, 1974) is only a small part of that available.

139. See Le Clercq, supra note 9 , at $33-35$ n.114.

140. The Neustadts had bought their house under $\$ 203$ in 1957. The code-compliance requirement was first enacted in 1959 and apparently has never applied to $\$ 203$ houses. 
behind $\S 203 .{ }^{141}$ Under traditional rules of statutory construction, ${ }^{142}$ a statutory provision is not to be read as being merely repetitive and superfluous if it can be read in another way, and the code-compliance requirement is superfluous if protecting FHA financially is its only goal. Even if a house is sub-code, FHA will not be hurt financially at all if the appraised price accurately reflects the substandard condition of the house and the cost of repairs needed to bring it up to code, adjusted, perhaps, for the degree of code enforcement customary in the locale involved. ${ }^{143}$

On this basis it can be argued that there is indeed a legal relationship between the FHA and at least those individuals who became mortgagors under $\$ 235$ or $\$ 221$ (d)(2), even if not those under $\S 203 .{ }^{144}$ However, there remains the problem of just how far the Tucker Act reaches here. At least two courts ${ }^{\mathbf{1 4 5}}$ have dismissed Tucker "Act of Congress" complaints by low-income homeowner plaintiffs on the basis of Eastport Steamship Corp. v. United States. ${ }^{146}$ Eastport concluded that the only noncontractual claims cognizable under the Tucker Act are those where the United States has improperly exacted

141. See Exploiting the Home-Buying Poor, supra note 2, at 526-29; Plaintiffs' Brief at 11-18, Massey v. Lynn, Civil No. 39822 (E.D. Mich. June 27, 1974), appeal docketed, Civil No. 74-2122, 6th Cir., Oct. 14, 1974; Brief for Appellants at 18-23, Jackson v. Romney, 355 F. Supp. 737 (D.D.C. 1973), aff'd sub nom. Jackson v. Lynn, Civil No. 73-1510 (D.C. Cir. Oct. 17, 1974) (renumbered from Civil No. 775-72); Le Clercq, supra note 9, at 44 n.151.

142. See 73 AM. Jur. 2D Statutes $\$ 250$, at 423-24 (1974); 82 C.J.S. Statutes $\$ 326$, at $630-31$ (1953).

143. A related argument is that:

It is of great moment that 12 U.S.C. $\$ 1715 l(d)(2)$ requires conformity of properties

to both the standards prescribed by the Secretary and to the requirements of all State laws or local ordinances, or regulations relating to the public health, or safety, zoning, or otherwise.... As the FHA Minimum Property Standards Manual acknowledges, '... building code[s] ... are primarily concerned with factors of health and safety and not the many other aspects of design and use which are included herein as essential for mortgage insurance determinations.' Had Congress been concerned only with the security of FHA insured mortgages, as is the case in the $\$ 203$ Neustadt situations, the Minimum Property Standards would be sufficient to satisfy Congressional policy.

Le Clercq, supra note 9, at 77-78.

144. See pp. 320-22 infra.

145. These are: (1) Davis v. Romncy, 355 F. Supp. 29, 46-48 (E.D. Pa. 1973), aff'd on other grounds, 490 F.2d 1360 (3d Cir. 1974) (It is true that the Third Circuit explicitly "reject[s] any statement.... contained in Eastport... on which the court below relied [in dismissing for lack of jurisdiction]," $490 \mathrm{~F} .2 \mathrm{~d}$ at 1371, but it "do[es] not pass on the scope of the Tucker Act's waiver of sovereign immunity ...."Id. at 1372. The same Eastport type of reasoning might well have led the Third Circuit to find jurisdiction but to dismiss for failure to state a claim upon which relief could be granted.); (2) Nash v. Romney, Civil No. 72-1313-RJK, at I1 (C.D. Cal. Oct. 15, 1973) (which quotes the lower Davis court with approval on precisely this point, although it does not actually cite Eastport directly). See Jackson v. Romney, 355 F. Supp. 737, 739-41 (D.D.C. 1973), aff'd sub nom. Jackson v. Lynn, Civil No. 73-1510 (D.C. Cir. Oct. 17, 1974) (uses somewhat similar reasoning, even if not explicitly citing Eastport).

146. 372 F.2d 1002 (Ct. Cl. 1967). 
or retained money from the plaintiff, or where the relevant statute, regulation, or constitutional provision "command $[s]$, in itself and as correctly interpreted," payment of money to the plaintiff. ${ }^{147}$

Although Eastport analyzes several cases in reaching its conclusion, it does not cite any cases specifically voicing its precise interpretation of the Tucker Act's limits. ${ }^{148}$ Nevertheless, there are some cases which may be viewed as logical precursors of the Eastport rule. ${ }^{140}$ Moreover, although it certainly seems possible to read the Tucker Act less restrictively, research discloses no case in which a nonmonetary right created by statute has been held sufficient to give rise to Tucker Act relief. ${ }^{150}$ There are numerous cases ${ }^{151}$ in which courts have remedied the deprivation of nonmonetary federal rights by ordering damages-but in none of those cases has the United States or one of

147. Id. at 1007-08 (emphasis added).

148. See 372 F.2d at 1008-10. Indeed, the United States as defendant hardly pushed this point, discussing it only in passing (with no case citations) on two pages of its 70 page brief. Certainly the construction of the Tucker Act in Eastport, while plausible, is not necessary.

149. In Pine Hill Coal Co. v. United States, 259 U.S. 191, 196 (1922), the Supreme Court said that "liability for ... the consequences of a law, on the part of the legislating power, is most unusual, and where... the liability would mount to great sums, only the plainest language could warrant a Court in taking it to be imposed." In Creek Nation v. United States, 318 U.S. 629 (1943) the Court held that "[a] promise by the government to try to keep the peace is not equivalent to a promise to make payments if the peace is not kept ...."Id. at 634. It is noteworthy that in Creek Nation, the treaty provided that "the United States guarantees [to the Creeks] quiet possession of their country...," see id. at 633 , and that the jurisdictional statute (Act of May 24, 1924, ch. 181, 43 Stat. 139 (noted at 318 U.S. at 630 n.1)) was more broadly worded than is the Tucker Act, in that it covered "any and all legal and equitable claims arising under or growing out of any treaty or agreement between the United States and the Creek Indian Nation ...." (Em. phasis added.) (Note that this emphasized language was not stressed by the plaintiffs in their briefs, and that the Court quotes the Act merely as giving jurisdiction "over claims under 'any treaty or agreement between the United States' and these tribes." 318 U.S. at 630.) Similar holdings appear in Leighton v. United States, 161 U.S. 291, 296-97 (1896), and in Roden Coal Co. v. United States, 95 Ct. Cl. 219, 231 (1941), cert. denied, 317 U.S. 636 (1942).

150. The Davis district court despite "extensive research" also was unable to find a single case "which support[s] or even suggest[s] that an implied cause of action [for monetary damages] can find its jurisdictional basis in the Tucker Act." 355 F. Supp. at 48.

151. Bivens v. Six Unknown Named Agents of Fed. Bureau of Narcotics, 403 U.S. 388 (1971); J.I. Case Co. v. Borak, 377 U.S. 426 (1964); Texas \& Pac. Ry. v. Rigsby, 241 U.S. 33 (1916). Numerous cases contain language to the effect that implied money damages are awardable under the Tucker Act as compensation for statutorily granted rights. See, e.g., United States v. Wickersham, 201 U.S. 390 (1906); Chambers v. United States, 451 F.2d 1045 (Ct. Cl. 1971); Carter v. United States, 407 F.2d 1238 (Ct. C1. 1968); Fletcher v. United States, 392 F.2d 266 (Ct. Cl. 1968); Watson v. United States, 162 F. Supp. 755 (Ct. Cl. 1958); Stringer v. United States, 90 F. Supp. 375 (Ct. CI. 1950). The problem with these cases is that they all involve statutes granting the right to money (here, to back pay). This is also true in the following cases having such language about implied money damages: Menkarell v. Bureau of Narcotics, 463 F.2d 88 (3d Cir. 1972) (inverse condem. nation compensation-see note 113 supra); Mayor \& Council v. United States, 162 F. Supp. 243 (D. Del. 1957) (payments due to a city from a federally assisted public housing authority); Betts v. United States, 172 F. Supp. 450 (Ct. Cl. 1959) (military disability compensation). Thus the language referred to in these decisions can be viewed purely as dicta, and the decisions as not inconsistent with Eastport. 
its agencies been the defendant. There are, on the other hand, a great many cases ${ }^{152}$ which hold that the Tucker Act, as a relinquishment of sovereign immunity, must be strictly interpreted. ${ }^{153}$ Finally, it should be noted that " $[\mathrm{t}]$ he settled doctrine is that only Congress can waive immunity from suit." 154 It is not illogical to view the enactment of $\S 518(b)^{155}$ as an expression of opinion by Congress that it had not otherwise waived sovereign immunity with respect to this type of claim by low-income homeownership plaintiffs. ${ }^{156}$

The Tucker Act "Act of Congress" jurisdiction also does not apply to any rights granted to $\S 235$ home buyers by $\S 518(b)$, since $\S 518(c)^{157}$ explicitly provides that the HUD Secretary's "decisions regarding expenditures or payments [under $\$ 518(b)$ ], and the terms and conditions under which the same are approved or disapproved, shall be final and conclusive and shall not be subject to judicial review." It is well established that where the United States "creates rights in individuals against itself, [it] is under no obligation to provide a remedy through the courts," 158 and "where a statute creates a right and provides a special remedy, that remedy is exclusive."158

\section{Contract Claims}

There have also been at least two $\operatorname{cases}^{160}$ brought on the theory that the plaintiffs have a claim founded upon contracts with the United States. The plaintiffs allege express and implied contracts, and also third party beneficiary theory:

152. See United States v. Sherwood, 312 U.S. 584, 590 (1941).

153. There are some cases calling for liberal construction-e.g., United States v. Emery, Bird, Thayer Realty Co., 237 U.S. 28 (1915)-but these cases seem to be in the minority.

154. Developments, supra note 113 , at $878 \mathrm{n} .838$.

155. See p. 303 supra.

156. See Nash v. Romney, Civil No. 72-1313-RJK, at 5 (C.D. Cal. Oct. 15, 1973). Of course, this is not a necessary construction, either. Consider Le Clercq, supra note 9, at 44 n.15I: "If there were questions about Congressional intent with regard to the rights of low income housing consumers subsidized under $\$ 235$, it was removed by legislative history of the Housing and Urban Development Act of 1970.... All too often, the FHA has viewed its role as a neutral middleman in a business transaction. As a government agency the FHA has an obligation to ensure that purchasers of section 235 homes are not misled into paying an exorbitant price or purchasing a seriously defective dwelling on the basis of the FHA appraised price and approval of subsidy payments.' S. REP. No. 1216, 9lst Cong., 2d Sess. 6.7 (1970)."

157. See note 82 supra.

158. United States v. Babcock, 250 U.S. 328, 331 (1919). See Glidden Co. v. Zdanok, 370 U.S. 530, 573 (1962).

159. Id.

160. Cason v. United States, Civil No. $19025-2$ (W.D. Mo. Apr. 5, 1973) (partial summary judgment denying damage claim), (W.D. Mo. July 8, 1974) (dismissing other claims), appeal docketed, Civil No. 74-1672, 8th Cir., Aug. 23, 1974; Massey v. Lynn, Civil No. 39822 (E.D. Mich. June 27, 1974), appeal docketed, Civil No. 74-2122, 6th Cir., Oct. 14, 1974. 
The mortgagor as part of his monthly payment pays an FHA insuring premium. Surely the exchange of consideration between the mortgagor-purchaser and the FHA establishes an expressed [sic] contract as well as an implied contract which falls within the purview of the Tucker Act. Furthermore, the mortgagor-purchaser is certainly a third-party beneficiary to any agreement which is executed between the mortgagee and FHA. ${ }^{161}$

It is hard to credit these contract contentions. It is the mortgagee, not the mortgagor-buyer, who directly pays the premium to the FHA. ${ }^{162}$ This is logical, since the premium is the consideration paid to FHA for FHA's doing the service for the mortgagee of insuring the mortgage that the mortgagee holds. It is true that the mortgagee does not have to absorb the cost of the premium himself; the law allows him to pass the cost on to the mortgagor. ${ }^{163}$ But this arrangement is different from one in which the mortgagor directly pays a fee to the FHA in return for the FHA's warranting or guaranteeing the house that the mortgagor is to receive. The significance of the (indirect) premium payments was not directly argued in Neustadt, but it seems a weak basis on which to attack the holding there that "there is no legal relationship between the FHA and the individual mortgagor."164

Unfortunately, plaintiffs' third party beneficiary argument is also flawed. The FHA does not covenant with the mortgagee that the FHA will inspect or appraise the house (and certainly not that it will inspect or appraise the house in a non-negligent manner). Indeed, the fact that the loan is insured makes the mortgagee quite unconcerned about getting a promise from FHA that it will not overappraise the home or approve a sub-code home. ${ }^{105}$ If anyone has breached a promise meant for the benefit of the home buyer in a contract between the United States and the mortgagee, it is the mortgagee in situations where the FHA has simply noted a significant defect and left it solely to the mortgagee to provide certification that the defect was removed or corrected. ${ }^{168}$ Thus, if the plaintiffs are to sue anyone as third party

161. Plaintiffs' Suggestions on Defendants' Motion to Dismiss at 15, Cason v. United States, Civil No. 19025-2 (W.D. Mo. Apr. 5, 1973) (partial summary judgment denying damage claim), (W.D. Mo. July 8, 1974) (dismissing other claims), appeal docketed, Civil No. 74-1672, 8th Cir., Aug. 23, 1974. See also Plaintiffs' Brief at 44-53, Massey v. Lynn, Givil No. 39822 (E.D. Mich. June 27, 1974), appeal docketed, Civil No. 74-2122, 6th Cir., Oct. 14, 1974 .

162. 12 U.S.C. $\$ \$ 1709(\mathrm{~b})(6), 1709(\mathrm{c})(1970)$.

163. Id. $\$ 1715 l(\mathrm{~d})(2)$.

164. See note 137 supra.

165. See pp. 296-97 \& note 30 supra.

166. Thus, the Brief for Appellants at 7-8, Davis v. Romney, 490 F.2d 1360 (3d Cir. 1974), alleged that the HUD Philadelphia office often insured mortgages on houses in 
beneficiaries, the one to be sued is the mortgagee, not the United States. Third party beneficiary theory might in some respects provide an easier route toward recovery against the mortgagee than does fraud, ${ }^{187}$ but it does not advance plaintiffs any further as against the United States. ${ }^{188}$

\section{Suing the United States for Damages under the Federal Tort Claims Act}

The major remaining waiver of federal sovereign immunity ${ }^{169}$ is the Federal Tort Claims Act (FTCA). ${ }^{170}$ Subject to specified exceptions, ${ }^{171}$ it allows the United States to be sued

for money damages ... for injury or loss of property, or personal injury or death caused by the negligent or wrongful act or omission of any employee of the Government while acting within the scope of his office or employment, under circumstances where the United States, if a private person, would be liable to the claimant in accordance with the law of the place where the act or omission occurred.172

Several suits have been brought by low-income homeownership participants under the FTCA, ${ }^{173}$ but several plaintiffs' attorneys, out of fear of the Neustadt case, ${ }^{174}$ have chosen to emphasize instead one

which the HUD appraisers had spotted "obvious and serious defects," and in which HUD had no information leading it to believe that those defects had been repaired except "certifications from non-existent companies and from persons having an interest in the property, mortgagee, broker or seller." For some corroboration of this, see STAFF REPORT, supra note 35 , at 28,37 .

167. See Connor v. Great W. Sav. \& Loan Ass'n, 69 Cal. 2d 850, 447 P.2d 609, 73 Cal. Rptr. 369 (1968); Morrocco v. Felton, 112 N.J. Super. 226, 270 A.2d 739 (1970). See also pp. 300.01 supra.

168. In connection with this "contract" section of the Tucker Act, note that at most there might be a contract implied in law here, and it has repeatedly been held that the Tucker Act does not cover contracts implied in law, although it may cover contracts implied in fact. See, e.g., Merritt v. United States, 267 U.S. 338, 340-41 (1925); Stewart Sand \& Material Co. v. Southeast State Bank, 318 F. Supp. 870, 874 (W.D. Mo. 1970).

169. Davis, Sovereign Immunity Must Go, 22 AD. L. REv. 383, 385, 403 (1970). (The Court of Claims Act of 1855, Act of Feb. 24, 1855, ch. 122, $\S 1,10$ Stat. 612, is the basis of current 28 U.S.C. $\S 1491(1970)$ and is the precursor of the Tucker Act.)

170. 28 U.S.C. $\$ \S 1346(\mathrm{~b}), 2674-80$ (1970).

171. Id. $\$ 2680$.

172. Id. \$1346(b).

173. Perry v. Romney, Civil No. 9347 (W.D. Wash. Apr. 5, 1971), appeal dismissed as moot, 472 F.2d 565 (9th Cir. 1973); Cason v. Ünited States, Civil No. 19025-2 (W.D. Mo. Apr. 5, 1973) (partial summary judgment denying damage claim), (W.D. Mo. July 8, 1974) (dismissing other claims), appeal docketed, No. 74-1672, 8th Cir., Aug. 23, 1974; Williams v. United States, Civil No. KC-3346 (D. Kan., filed June 8, 1971); Brown v. United States, Civil No. 18943-2 (W.D. Mo., filed Dec. 23, 1970), dismissed without prejudice (Apr. I, 1971).

174. United States v. Neustadt, 366 U.S. 696 (1961). 
or more of the APA and Tucker Act bases for suit discussed above. ${ }^{175}$ Neustadt held ${ }^{170}$ that FTCA recovery was barred to a $\$ 203^{177}$ home buyer who had relied on an excessive FHA appraisal,178 because of the section ${ }^{179}$ of the FTCA which exempts the United States from liability for "any claim arising out of . . . misrepresentation [or] deceit . . . ." The Court added ${ }^{180}$ that no other tort was present on which the Neustadts could recover since there was "no legal relationship between the FHA and the individual [\$ 203] mortgagor."181

There are solid grounds on which Neustadt can be distinguished, even though one cannot be certain that the courts will use them. The Neustadts specifically alleged ${ }^{182}$ that they had relied upon the FHA appraisal statement to disclose any substantial deficiency or defect in the property. In contrast, many of the low-income homeownership plaintiffs were never told anything about the value or condition of the property by anyone from FHA, ${ }^{183}$ and many could not have read any forms that they might have been given which might have shown the appraised value or purported to make a statement about code-compliance. ${ }^{184}$ To the extent they relied on government action at all, they "relied" on the government in a more subtle sense. Unscrupulous or careless realtors and sellers apparently had a strong selling point when they represented that the sale was under a government program, and thus that the buyer had no reason to be concerned about deficient housing. ${ }^{185}$

175. Telephone Interview with Thomas C. Carey, Esq., Legal Aid attorney for Massey (of Massey v. Lynn, Civil No. 39822 (E.D. Mich. June 27, 1974), appeal docketed, No. 742122, 6th Cir., Oct. 14, 1974), March 1, 1974. Several other attorneys have expressed similar sentiments. See also Exploiting the Home-Buying Poor, supra note 2, at 566; Abuses, supra note 2 , at $479-80$.

176. 366 U.S. at 711 .

177. See note 20 supra; 366 U.S. at 697 n.2.

178. FHA appraised the property at $\$ 22,750$ for mortgage insurance purposes; Neustadt paid $\$ 24,000$ for the house; and its value, because of poor soil conditions, was later found to have been no more than $\$ 16,000$. 366 U.S. at 699.701 .

179. 28 U.S.C. $\$ 2680(\mathrm{~h})(1970)$.

180. 366 U.S. at 706-11.

181. See note 137 supra.

182. Record at 1.

183. See Special Project, supra note 28, at 132: "Less than seventeen percent (17\%) of the homeowners interviewed had ever talked to or had any correspondence with any government official." See also, as to the $\$ 226$ requirement (p, 310 supra), Plaintiff' Suggestions on Defendants' Motion to Dismiss at 4 , Cason v. United States, Civil No. 19025-2 (W.D. Mo. Apr. 5, 1973) (partial summary judgment denying damage claim), (W.D. Mo. July 8, 1974) (dismissing other claims), appeal docketed, No. 74-1672, 8th Cir., Aug. 23, 1974: "Section 226 of the National Housing Act of 1954 which requires the disclosure to the buyer prior to sale, of the FHA appraisal, which was considered to be an important fact of the basis of the plaintiff's [sic] case in Neustadt, is in fact rarely complied with by mortgagees in Kansas City, Missouri."

184. See, e.g., Exploiting the Home-Buying Poor, note 2 supra at 525.

185. See, e.g., Exploiting the Home-Buying Poor, note 2 supra, at 525, 537-38. Thus, these low-income homeownership participants may have reasonably relied on govern- 
Even if some element of government misrepresentation were present in some cases, moreover, the Court in Neustadt indicated that the mere presence of such an element does not in itself completely disqualify a plaintiff from any recovery under the FTCA if some different, independent tort is present:

[A] Torts Act claim for property damages suffered when a vessel ran aground as a result of the Coast Guard's allegedly negligent failure to maintain the beacon lamp in a lighthouse ... does not "arise out of ... misrepresentation," any more than does one based upon a motor vehicle operator's negligence in giving a misleading turn signal. As Dean Prosser has observed, many familiar forms of negligent conduct may be said to involve an element of "misrepresentation," in the generic sense of the word . . . . 186

There is thus a crucial distinction between negligent misrepresentation and negligence which simply involves an element of communication. The Court's care in pointing out this distinction has been followed in several later lower court decisions. ${ }^{187}$

ment protection and yet not have been subject to misrepresentation by the government (unless one considers the enactment of a statute which induces reasonable expectations of, and reliance on, government protection which does not in fact materialize as constituting misrepresentation-an unlikely holding under local tort law, which governs under the FTCA, 28 U.S.C. $\$ 1346$ (b) (1970)).

186. 366 U.S. at 711 n.26. The passage from Neustadt quoted in the text continues, "but "[s]o far as misrepresentation has been treated as giving rise in and of itself to a distinct cause of action in tort, it has been identified with the common law action of deceit,' and has been confined 'very largely to the invasion of interests of a financial or commercial character in the course of business dealings.' Prosser, Torts, $\$ 85$... . Does the Court mean that there may be $\$ 2680(\mathrm{~h})$ misrepresentation (and hence no recovery) when certain acts cause pecuniary harm in business dealings, but that there is not $\$$ 2680(h) misrepresentation when identical acts wind up causing physical harm? Such a differentiation seems illogical. But see Note, Federal Tort Claims Act-Governmental Liability for Negligent Chart Publication \& Aircraft Certification, 19 Wayne L. REv. 1201, 1218 (1973) [hereinafter cited as Chart Publication]: "A limitation on the use of the misrepresentation exception seems to be emerging.... There appears to be a basic distinction between cases based on government acts resulting in death and injury, and cases causing monetary loss from business transactions." See also Note, The Federal Seal of Approval: Government Liability for Negligent Inspection, 62 GEo. L.J. 937, 947, 958 (1974) [hereinafter cited as Federal Seal].

187. See Ingham v. Eastern Air Lines, Inc., 373 F.2d 227, 239 (2d Cir.), cert. denied, 389 U.S. 844 (1967): "The government's reading of the misrepresentation exception is much too broad, for it would exempt from tort liability any operational malfunction by the government that involved communication in any form.... Where the gravamen of the complaint is the negligent performance of operational tasks, rather than misrepresentation, the government may not rely upon $\$ 2680(\mathrm{~h})$ to absolve itself of liability." See also Hungerford v. United States, 307 F.2d 99, 103 (9th Cir. 1962): "Where the government, on the basis of facts which it is chargeable with ascertaining by a proper examination, has a duty to perform in addition to the duty of disclosing those facts, negligence in the conduct of such examination which results in a failure to perform the additional duty is not covered by the $\$ 2680(\mathrm{~h})$ exception." See also Beech v. United States, 345 F.2d 872, 874 (5th Cir. 1965): "Here, the Government had not only the duty to communicate to MIrs. Beech a diagnosis of her condition, but also to render proper care for her treatment. Under the allegations of the complaint there was a failure to perform this latter duty and such failure is not covered by the 2680(h) exception." See also United Air Lines, 
The next question, then, is whether some other tort was present in the current cases. Several other possible torts do exist: for example, the negligent inspection in itself,, ${ }^{188}$ negligence (perhaps negligence per $\mathrm{se}^{189}$ ) in unlawfully ${ }^{190}$ approving mortgage insurance on a subcode house, ${ }^{191}$ breach of a duty to rescue the plaintiffs from a peril

Inc. v. Wiener, 335 F.2d 379, 398 (9th Cir.), cert. dismissed, 379 U.S. 951 (1964); Federal Seal, note 186 supra, at 946-47, 958. But see Note, Federal Tort Claims Act: Exceptions to the Waiver of Sovereign Immunity, 27 JAG J. 283, 289 \& n.33 (1973). Other courts have held that where two torts are present, the fact that relief for one is barred by an FTCA exception does not preclude relief for the other. Quinones v. United States, 492 F.2d 1269, 1275-76, 1280-81 (2d Cir. 1974); Rogers v. United States, 397 F.2d 12 (4th Cir. 1968).

188. Of course, there would have to have been a duty on FHA's part to protect the plaintiff, and the negligent inspection would have to have been the proximate cause of the harm that resulted to the plaintiff. See W. Prosser, HANDbook of THE LAw of Torts $\$ 30$ (4th ed. 1971), which identifies the following as "[ $[$ ] he traditional formula for the elements necessary to...a cause of action [founded upon negligence, from which liability will follow: ... I. A duty, or obligation, recognized by the law, requiring the actor to conform to a certain standard of conduct, for the protection of others against unreasonable risks. 2. A failure on his part to conform to the standard required....3. A reasonable [sic] close causal connection between the conduct and the resulting injury...; [i.e.,] 'proximate cause.' 4. Actual loss or damage resulting to the interests of another." (Footnotes omitted.) As to whether the government had a duty as to the home buyers to inspect non-negligently, see pp. 320-22 infra. On the question whether the negligent inspection was the proximate cause of plaintiff' harm, consider that if a proper inspection had been made-disclosing the lack of code compliance-the mortgage insurance could not have been issued and as a result the plaintiffs could not possibly have bought the houses with all the defects complained about. See also note 191 infra.

For an example of a case where the United States was held liable (under the Suits in Admiralty Act, 46 U.S.C. $\$ \$ 741-52$ (1970); the FTCA was not mentioned in the opinion) for negligence which included in part a negligent inspection, see Rapp v. Eastern Airlines, Inc., 264 F. Supp. 673 (E.D. Pa. 1967) [vacated upon stipulation of settlement, Civil No. 16,847 (3d Cir. 1970) according to Chart Publication, supra note 186, at 1211 n.71]. There, $264 \mathrm{~F}$. Supp. at $680-81$, the court found that " $[t]$ he government was negligent... in failing to provide for further tests in determining the outcome when the Electra [airplane] would meet a flight of birds and ingest them on take-off." But see Marival, Inc. v. Planes, Inc., 306 F. Supp. 855 (N.D. Ga. 1969).

189. See Wildwood Mink Ranch v. United States, 218 F. Supp. 67, 70-74 (D. Minn. 1963) (negligence per se where Navy planes flew below the minimum altitude fixed by federal regulation having the force of statute). Wildwood seems to be the only case where violation of a federal statute (or regulation having force of statute) has been held to be negligence per se. But cf. Somerset Seafood Co. v. United States, 193 F.2d 631, 635 (4th Cir. 1951).

190. See pp. 307-09 supra.

191. Note that such an argument (i.e., that approving the mortgage insurance negligently was a tort separate from the negligent appraisal/misrepresentation tort) was put forth by the Neustadts on appeal to the Supreme Court (although they had not raised this argument before, and although no unlawfulness in approving the insurance was alleged). The Neustadts' purchase contract for the house had been conditional upon their getting a loan secured by an FHA-insured mortgage (at its lower-than-conventionalmortgage-rates), so that "[i]t was the availability of this insurance and not the receipt of the appraisal report that caused them to purchase the defective house. Had that mortgage insurance not been issued the [Neustadts] could not and would not have purchased the house." (Respondents' Brief at 26-27.) The Court never directly made reference to this argument, and Neustadt certainly cannot be considered conclusively to reject it, particularly in light of the Court's care, 366 U.S. at $711 \mathrm{n.26}$, in reaffirming the continued effectiveness of Indian Towing Co. v. United States, 350 U.S. 61 (1955). See pp. $310-11$ supra and pp. 320.22 infra, on the question of whether such a relationship and duty toward the low-income home buyer current plaintiffs should be found to exist.

As to proximate cause, clearly the approval of the mortgage insurance (and/or the granting of the subsidy under $\$ 235$ to the home buyer: see p. 295 supra) was a causc in fact of the plaintiff' injury: The low-income homeownership programs are aimed 
into which the United States contributed in placing the plaintiffs, ${ }^{192}$ and breach of a duty to warn. ${ }^{193}$

These torts face two possible additional obstacles. First, the FTCA has, in addition to the exceptions for misrepresentation and deceit, an exception for "the exercise or performance or the failure to exercise or perform a discretionary function or duty on the part of a federal agency or an employee of the Government, whether or not the discretion involved be abused." 194 Second, and interrelated, is the "no legal relationship" holding in Neustadt.105 If that holding were to apply to these low-income homeownership plaintiffs, it would negate any government "duties," or "fiduciary relationship" to the plaintiffs.

As previously discussed, ${ }^{100}$ the terms of the code-compliance requirement $^{197}$ are not themselves discretionary. It appears settled ${ }^{198}$

preciscly at those who, but for the FHA insurance of their "too risky" (marketwise) mortgages (and/or the $\$ 235$ subsidy), could not otherwise have bought the houses that they bought under the programs. See p. 296 supra; note 28 supra; Le Clercq, supra note 9, at 7-11. But see note 24 supra. In addition, the harm that resulted could reasonably have been foreseen by the government (particularly after the initial scandals-see p. 298 supra-and probably even before as well, since the major elements leading to the scandals (pp. 296-97 supra) were clearly foreseeable). In regard to "reasonable forcsecability," note the rule that "if [an individual] has in fact knowledge, skill, or even intelligence superior to that of the ordinary man, the law will demand of him conduct consistent with it." Prosser, supra note 188 , at 161 (footnotes omitted). Note also the rule that an individual "may... be engaged in an activity, or stand in a relation to others, which imposes upon him an obligation to investigate and find out, so that he becomes liable not so much for being ignorant as for remaining ignorant . . . "Id. at 160 (footnotes omitted).

192. See 2 Restatement (SECOND) OF ToRTs $\$ \$ 321-24$ (1965). The Restatement would limit liability in this regard to "physical harm" or "bodily harm." This would not help all of the current plaintiffs and would not be a complete remedy even for those whom it would help, but note that it would help at least some of the current plaintiffs. See pp. 298, 299 supra; W. Prosser, supra note 188, $\$ 56$, at 340-43.

193. See Note, The Duty to W'arn and the Urban Riot: The Jahnke Case, 58 Iown L. REv. 447, 450-62 (1972). Such a duty could arise from the implication of a fiduciary relationship or confidential relationship between the United States and the current plaintiffs (see note 207 infra; 37 AM. JUR. 2D Fraud \& Deceit $\$ 149$ (1968)) or from vol. untary assumption of a duty to inspect and/or warn and/or protect which has engendered rcliance (see 35 AM. Jur. 2D Federal Tort Claims Act $\$ 84$ (1967)), and note that the Court in Neustadt specifically affirmed-366 U.S. at 711 n.26-the continuing vitality of Indian Towing Co. v. United States, 350 U.S. 61 (1955), discussed in note 199 infra. See Underwood v. United States, 356 F.2d 92, 98 (5th Cir. 1966); Fair v. United States, 234 F.2d 288, 293-94 (5th Cir. 1956).

194. 28 U.S.C. \$ 2680 (a) (1970).

195. 366 U.S. at 709 .

196. See pp. 308-09 supra.

197. See p. 308 supra.

198. See Eastern Air Lines, Inc. v. Union Trust Co., 221 F.2d 62 (D.C. Cir.), aff'd per curiam sub nom. United States v. Union Trust Co., 350 U.S. 907 (1955). A government air traffic controller failed to follow CAA-prescribed Standard Airport Traffic Control Procedures, and thus contributed to a collision of two airplanes. The Procedures had been promulgated under authority of the Civil Aeronautics Act of 1938 and had bind. ing force, yet the United States argued that it was discretionary for the tower operators as to whether to follow the procedures, since the tower operators' duties "involve the exercise of discretion and judgment, with the result that neither the operators nor the United States can be held liable for their negligent performance." Id. at 75. The court 
that an agency's decision to follow or to ignore such mandatory provisions of a statute or binding regulation is not itself a discretionary act within this FTCA exception. Moreover, even as to activities that the government could have exercised discretion not to undertake, once the government has elected to undertake them and has engendered reliance on its performance of those activities, negligence in performance is not within the "discretionary function" exception. ${ }^{100}$

The remaining key question, then, is whether in enacting the codecompliance requirement, or in establishing the $\$ \$ 235$ and 221 (d)(2) programs, the United States assumed any duties vis-à-vis the low-income homeownership plaintiffs. ${ }^{200}$ In Neustadt, which dealt with $\$ 203$ 's appraisal requirement, this question was answered in the negative. $^{201}$ Perhaps Neustadt was ill-considered and ought to be overruled, ${ }^{202}$ but in any event the present cases, which arise under $\$ \$ 235$ and $221(\mathrm{~d})(2)$, are distinguishable from Neustadt on the facts: In addition to the general differences between the legislative history,

rejected this argument, holding that "the tower opcrators merely handle operational details which are outside the area of the discretionary functions and duties referred to in $\$ 2680$ (a); and that, consequently, the Tort Claims Act permits the Government to be sued for damages sustained because of their negligence." Id. See also Hatahley v. United States, 351 U.S. 173 (1956); Somerset Seafood Co. v. United States, 193 F.2d 631 (4th Cir. 1951).

199. Indian Torving Co. v. United States, 350 U.S. 61, 69 (1955). The Coast Guard had allowed a lighthouse to get out of working order, resulting in plaintiff's tugboat going aground, damaging the cargo that it was towing. The Court rejected the government's attempt to get within the $\$ 2680(a)$ "discretionary function" exception:

The Coast Guard need not undertake the lighthouse service. But once it exercised its discretion to operate a light on Chandeleur Island and engendered reliance on the guidance afforded by the light, it was obligated to use due care to make certain that the light was kept in good working order; and, if the light did become extinguished, then the Coast Guard was further obligated to use due care to discover this fact and to repair the light or give warning that it was not functioning. If the Coast Guard failed in its duty and damage was thereby caused to petitioners, the United States is liable under the Tort Claims Act.

In the same vein is Fair v. United States, 234 F.2d 288, 293-94 (5th Cir. 1956). The United States here was held liable for damages for the deaths of three people shot by an Air Force officer who had been released from an Air Force hospital where he had threatened the life of one of those that he was to shoot. His doctors knew of the threats and failed to keep their promise to give advance notification of his release to the person that he had threatened so that precautions could be taken. The court rejected a $\$ 2680$ (a) challenge, holding that "if the Government undertakes to perform certain acts or functions thus engendering reliance thereon, it must perform them with due care . . . " Accord, Underwood v. United States, 356 F.2d 92 (5th Cir. 1966).

200. The torts under discussion seem clearly to involve the other elements of negligence discussed in note 188 supra.

201. See p. 310 supra.

202. Note, for example, the context from which the Court lifted the crucial "no legal relationship" words (see p. 310 supra):

Historically, the fundamental soundness of ... the FHA home mortgage system has rested on the integrity of its appraisal system.... [T] [Te FHA's appraisal system .... as well as ... its inspection system... are obviously essential to the proper underwriting of mortgage loan risks, and therefore operate primarily for the protection of the Government and its insurance funds. Nevertheless, Congress has consistently recognized-and intended-that, notwithstanding the fact that, technically there is no 
provisions, and operation of $\S 203$, and of $\$ \S 235$ and $221(\mathrm{~d})(2)$, Neustadt differs from the present cases in the type of plaintiffs involved, the type of harm suffered, the cause of the harms that occurred, and the reasonableness of reliance that the plaintiffs may have engaged in. Unlike these plaintiffs, Neustadt was an attorney ${ }^{203}$ and so presumably was neither ill-educated, poor, nor incapable of owning a home unless he could get mortgage insurance from the government. ${ }^{204}$ In addition, Neustadt apparently was rather sophisticated as a home buyer, admitting 205 that he had "considered the possibility of hiring someone to inspect the house in order to ascertain whether it was structurally sound." 206 The low-income homeownership plaintiffs are notably unsophisticated as to home buying ${ }^{207}$ and thus bargain with

legal relationship between the FHA and the individual mortgagor, these FHA procedures also operate for the benefit and protection of the individual home buyer. However, there has apparently been a strong tendency on the part of the FHA to view these procedures as operating exclusively for the protection of the Government and its insurance funds. The Committee of Conference does not believe such a view to be consistent with the intent of the Congress in respect of the basic legislation relating to the FHA in the past, and, as to the future, desire to make it abundantly clear that such is not the case.

In this connection, the committee of conference calls attention to... the provision [in the conference substitute bill] which requires that the seller or builder... shall agree to deliver, prior to the execution of a contract for the sale of the property, to the purchaser a written statement setting forth the amount of the FHA's appraised value of the property.

The committee of conference desires to point out the importance it attaches to... [that] provision.

H.R. REP. No. 2271, 83d Cong., 2d Sess. 66-67 (1954) (conference report). And the Senate

Committee on Banking and Currency had taken the position that

the first responsibility of Congress, and that of any agency administering part or all of the housing program, is to protect and preserve the public interest, in general, and the rights of homeowners in particular. It is your committee's considered opinion ... that the HHFA and its constituent agencies... shall at all times regard as a primary responsibility their duty to act in the interest of the individual home purchaser and in so doing to protect his interest to the extent feasible.

S. REP. No. 1472, 83 d Cong., 2d Sess. 4-5 (1954).

203. Record at 14, United States v. Neustadt, 366 U.S. 696 (1961).

204. See pp. 295, 296, 316 supra.

205. Record at 15, United States v. Neustadt, 366 U.S. 696 (1961).

206. He decided to rely on the FHA's appraisal, instead(l). Id.

207. See pp. 296, 316 supra. Indeed, these facts would all seem to permit the relationship between the FHA and the low-income home buyers to be treated as a fiduciary relationship or confidential relationship (see note 192 supra) or as a quasi-guardian/ward relationship (see Seminole Nation v. United States, 316 U.S. 286, 296-97 (1942); Cherokee Nation v. Georgia, 30 U.S. (5 Pet.) I, 17 (1831); Sac \& Fox Tribe v. United States, 383 F.2d 991, $1000-01$ (Ct. Cl.), cert. denied, 389 U.S. 900 (1967); Seneca Nation v. United States, $173 \mathrm{Ct}$. CI. 917, 925-27 (1965)), which should scem to satisfy the duty requirement.

Finally, consider Underwood v. United States, 356 F.2d 92, 98 (5th Cir. 1966), where the United States was held liable for the killing by an airman of his wife when one government doctor failed to furnish another with an adequate history of the airman's mental illness, causing the airman to be returned to duty where he had access to weapons and ammunition.

The United States argues that the Regulation and instructions were 'designed for the protection of the United States against theft or loss of ordnance.' We do not agree. The Regulation states that, 'Precautionary measures are needed to minimize accidents.' One of the instructions having to do with 'Firearms and Ammunition' expresses a purpose, 'To prevent serious injury to himself or to another person.' It 
the sellers on unequal terms. Neustadt's injury was purely a pecuniary one; his house developed cracks due to a soil problem, ${ }^{208}$ lowering its monetary value. The current plaintiffs have received houses that have posed health problems, led to personal injuries, and often turned out to be so dangerous as to be of negative value. Neustadt's harm clearly was caused by his reliance on the negligent FHA appraisal. FHA's action in Neustadt either was not a tort since reliance was unreasonable or it was at most the tort of negligent misrepresentation. The causes of the $\$ \$ 235$ and 221(d)(2) plaintiffs' harm were acts that fall outside of the misrepresentation exception to the FTCA.

\section{Conclusion}

That thousands of people have been victimized under the federal low-income homeownership program has been long and widely noted, and yet large numbers of these victims have been allowed to go remediless. This Note has argued that although relief seems unavailable under the Tucker Act and incomplete at best under the Administrative Procedure Act, it should be obtainable under the Federal Tort Claims Act, notwithstanding Neustadt. ${ }^{209}$

Nevertheless, congressional action is called for. Since the experience to date makes it obvious that widespread success in litigation is unlikely in the near future, ${ }^{210}$ improvement of $\$ 518$ administrative remedies is certainly desirable. ${ }^{211}$ More fundamentally, even eventual relief under the FTCA for the low-income homeownership plaintiffs will not overcome the major flaws in the FTGA statutory scheme revealed starkly during this long history of attempts to recover for damages inflicted because of a major administrative scandal. Thus, Congress should consider carefully whether it is still necessary or desirable for the United States to be held harmless for the deliberate torts of its employees now excepted under the FTCA. ${ }^{212}$ Congress

stretches the credible to say that at least one reason for maintaining tight control of firearms and ammunition was not the maintenance of safety. Clearly, we think, the precautionary measures were intended to minimize accidents and to prevent injury to persons; they were for the benefit of the public, including Mrs. Dunn.

It would not tax the imagination to apply these words to the cases under discussion in this Note.

208. 366 U.S. at 700.

209. United States v. Neustadt, 366 U.S. 696 (1961).

210. See note 4 supra.

211. On the defects of $\$ 518$, see pp. 305-06 supra.

212. 28 U.S.C. $\$ 2680$ (1970). "[T] he principal hole that unnecessarily remains in the Federal Tort Claims Act [is] the immunity from liability for specified deliberate torts. For no good reason-for no reason whatsoever disclosed in the legislative historygovernment liability was withheld for [the specified deliberate torts]. Illogical and unexplained are such exceptions along with government liability for [other deliberate torts]." Davis, supra note 169 , at 386. 
should also consider whether recovery under the FTCA should remain dependent on the vicissitudes of local tort law, ${ }^{213}$ particularly as to acts committed on a national scale by the federal government. Finally, because of the unconscionable delay in remedying the "homeownership for the poor" fiasco and because of the unique position and resources of the federal government, Congress might even use this occasion to consider whether the traditional tort requirement of duty or obligation on the part of the purported tortfeasor should continue to apply to the United States as defendant, particularly with respect to the least educated and most impoverished among the populace. Perhaps it is time for the United States to accept greater Good Samaritan affirmative duties than are borne by its individual citizens. ${ }^{214}$

213. 28 U.S.C. $\$ 1346(b)(1970)$. "The states often differ with regard to what constitutes tortious conduct, [so] it is not improbable that the Government may escape liability in one state and yet be liable for the same type of conduct in another." L. JAYson, HANdLing Federal TORT Claims: Administrative and Judicial Remedies \$ 218.01, at 9-147 (1972).

214. See Federal Seal, supra note 186, at 959 n.168. 